\title{
The effect of a transient frontal zone on the spatial distribution of extant coccolithophores around the Madeira archipelago (Northeast Atlantic)
}

\author{
Áurea Narciso $^{\mathrm{a}, \mathrm{b}, *}$, Rui Caldeira ${ }^{\mathrm{c}, \mathrm{d}}$, Jesus Reis ${ }^{\mathrm{c}}$, Mona Hoppenrath ${ }^{\mathrm{e}}$, Mário Cachão ${ }^{\mathrm{d}}$, \\ Manfred Kaufmann ${ }^{\mathrm{a}, \mathrm{b}, \mathrm{f}}$ \\ ${ }^{a}$ CIIMAR-Madeira, Caminho da Penteada, 9020-105, Funchal, Madeira, Portugal \\ ${ }^{\mathrm{b}}$ CIIMAR, University of Porto, Av. General Norton de Matos $s / n, 4450-208$, Matosinhos, Portugal \\ ${ }^{\mathrm{c}}$ Oceanic Observatory of Madeira (OOM), Edifício Madeira Tecnopolo, Piso 0, 9020-105, Funchal, Madeira, Portugal \\ ${ }^{\mathrm{d}}$ Dom Luiz Institute, Faculty of Sciences, University of Lisbon, 1749-016, Lisboa, Portugal \\ ${ }^{\mathrm{e}}$ Senckenberg am Meer, German Centre for Marine Biodiversity Research (DZMB), D-26382, Wilhelmshaven, Germany \\ ${ }^{\mathrm{f}}$ University of Madeira, Faculty of Life Sciences, Marine Biology Station of Funchal, 9000-107, Funchal, Portugal
}

\section{A R T I C L E I N F O}

\section{Keywords:}

Phytoplankton

Biodiversity

Ecology

Islands

Subtropical northeast Atlantic

\begin{abstract}
A B S T R A C T
In order to characterize the coccolithophore community around the Madeira archipelago and to understand the effect of a transient frontal zone on its distribution, 149 seawater samples from the first $150 \mathrm{~m}$ were collected in 37 stations, during the research cruise POS466 of RV Poseidon. The present study revealed the occurrence of two biogeographic domains, NE and SW, during the late winter of 2014, with distinct physical-chemical and calcareous nannoplankton characteristics. The NE sector was characterized by higher coccolithophore cell densities (mean of $56 \times 10^{3}$ cell $\mathrm{L}^{-1}$ ) and a slightly lower diversity (Margalef diversity index of 1.80) when compared with the SW sector (mean of $47 \times 10^{3}$ cell L ${ }^{-1}$; Md index of 1.86). The more productive sector, NE, was associated with colder, less saline and higher nutrient content water masses, linked to the injection of a westerly flow with origin in the Azores frontal system.

Total cell densities ranged between $12 \times 10^{3}$ and $112 \times 10^{3}$ cell $\mathrm{L}^{-1}$, being Emiliana huxleyi the dominant species followed by small Gephyrocapsa. The most common and subordinate taxa, in order of decreasing abundance, were: Gephyrocapsa oceanica, Michaelsarsia spp., Syracosphaera spp., Umbilicosphaera spp. and Algirosphaera robusta. Relationships between environmental conditions and spatial and vertical variability in coccosphere abundance, associated E. huxleyi and small Gephyrocapsa with the more productive water mass conditions, linked to the thermohaline transient front. G. oceanica distribution indicated its preference for warmer and less turbulent coastal waters, when compared to E. huxleyi and small Gephyrocapsa. Michaelsarsia spp. and A. robusta revealed preference for the northwest coast of Madeira, associated with mesotrophic conditions of the water column. Syracosphaera spp. and Umbilicosphaera spp. were well distributed throughout the archipelago and along the sampled depths, from the coast to open ocean conditions, as well as from lower to higher productive zones, displaying affinities for the meso to oligotrophic conditions, typical of these subtropical waters. The broad depth range of several taxa and the nonexistence of the coccolithophore vertical succession were the result of homogeneous and generalized well-mixed surface layer during the present survey.
\end{abstract}

\section{Introduction}

Phytoplankton biomass in the oceans constitutes about $1-2 \%$ of the total primary producers on earth (Falkowski, 1994). Despite its low biomass, these organisms contribute with approximately $46 \%$ per annum of the global primary production and carbon fixation (Falkowski et al., 1998; Field et al., 1998). They also play an important role in the oxygen cycle, releasing in the atmosphere about $40-50 \%$ of the global oxygen (Anderson, 2005). Due to its crucial involvement in climate regulation and biogeochemical cycles, marine phytoplankton has been increasingly targeted in global change studies. Coccolithophores are pelagic unicellular algae, which represent about $10 \%$ of the global phytoplankton biomass (Tyrrell and Young, 2009). Members of the Haptophyte class Prymnesiophyceae Hibberd, they are characterized by the ability to produce calcite platelets, at least by one of its life cycle stages. These structures, referred as coccoliths, surround the living cell

\footnotetext{
* Corresponding author. CIIMAR-Madeira, Caminho da Penteada, 9020-105, Funchal, Madeira, Portugal.

E-mail address: aurea.narciso@ciimarmadeira.org (Á. Narciso).
} 
and form an exoskeleton, the coccosphere (e.g. Winter and Siesser, 1994; Young, 1994). Known since the late Jurassic (Hay, 2004), these organisms are widely and abundantly distributed in the past and modern oceans, being one of the major contributors of pelagic carbonate on Earth (Honjo, 1996; Schiebel, 2002; Beare et al., 2013).

The Madeira archipelago is located in the subtropical Northeast Atlantic $\left(32.5^{\circ} \mathrm{N}, 17.0^{\circ} \mathrm{W}\right)$ and consists of the main island Madeira, Porto Santo ( $40 \mathrm{~km}$ to NE), the three small Desertas islands ( $25 \mathrm{~km}$ to $\mathrm{SE})$ and Selvagens islands ( $290 \mathrm{~km}$ to SE). The present study was conducted between Madeira and the neighboring Porto Santo and Desertas islands. These islands, also considered as "pre-seamounts" stages, form the two youngest parts of a volcanic chain of seamounts and islands of increasing age extending northeast towards the coast of Portugal, known as the Madeira Hot Spot Track (MHST) (Geldmacher et al., 2006).

The islands are situated at the eastern boundary of the North Atlantic Subtropical Gyre (NAST-E), with dominant northeastern trade winds and typical oligotrophic conditions (Longhurst, 1995), comprising in general nutrient-poor waters and low chlorophyll concentrations (about $0.2 \mathrm{mg} \mathrm{m}^{-3}$ in the upper portion of the euphotic zone), the proxy for phytoplankton biomass (Falkowski et al., 1998). Recent studies, based on several existing databases, refer coccolithophore biomass around $0.1 \mathrm{mg} \mathrm{C} \mathrm{m}^{-3}$ at the surface for the vicinity of Madeira archipelago, being this seasonally distributed and decreasing downward (O'Brien et al., 2013). Despite the relatively low biomass values, previous studies revealed an apparently high biodiversity of coccolithophores in these waters. Kaufmann (2004) recorded 37 different taxa resulting from one single sampling event of 3 different depths (15, 25 and $100 \mathrm{~m}$ corresponding to 55, 33 and 1\% light-depths) in October 2000. In a checklist of phytoplankton from waters off Madeira island, Kaufmann et al. (2015) reported 53 different taxa of coccolithophores, including the previous 37 taxa, supporting the general coccolithophore biogeography in which the greatest species richness is found in the tropical and subtropical zones, decreasing northward (Winter and Siesser, 1994).

The current study contributes to the characterization of the extant coccolithophore community dwelling in the Madeira archipelago, namely in what concerns the role of their islands and their associated oceanographic features in terms of variations in calcareous nannoplankton abundance, composition and distribution. Our study will also provide vital information for further comparison with seamount assemblages nearby, contributing to a better knowledge of the oceanic phytoplankton preferential development along the Madeira Hot Spot Track, as well as the evolution of ecosystems associated with the geomorphological evolution of the islands.

\section{Oceanographic setting}

The Madeira archipelago lies in a region strongly affected by the Azores Current/Front (AC/AF), the Portugal Current (PC) and the Canary Current (CC) (Fig. 1). A branch of the system AC/AF had already been consistently identified at the Madeira island latitude in several works (e.g. Käse and Siedler, 1982; Cromwell and Challengor, 1996; Pingree et al., 1999; Juliano and Alves, 2007). This westerly incoming flow was previously suggested to be the southern limit of the NE Atlantic subtropical front (Siedler et al., 1985). A clear temperature difference between the north and south coasts of Madeira island should reflect the presence of the above subtropical front, which position could shift throughout the year (Caldeira et al., 2002). A southern incoming surface flow, dominated by persistent southern wind episodes, is also observed during summer months (Caldeira and Sangrà, 2012).

Cold and productive cyclonic eddies, recognized by the cold core of upwelled water, are often detected southwest of Madeira island. Northern eddies are also identified, but are never as large as the southern ones (Caldeira and Sangrà, 2012). The formation of a warm island wake on the south coast of Madeira island is a typical late spring to early summer event, in result of the strongest winds (Caldeira et al., 2002). The formation of colder and nutrient-rich waters is detected at the island's flanks, particularly between Ponta de São Lourenço (SE Madeira) and the Desertas islands, where the underwater ridge connection seems to be responsible for the formation of upwelling cells (unpublished data). Apart from these local features, the incoming oceanic flows already transport mesoscale eddies, enriched in nutrients and organisms, which interact with the islands (Caldeira, 2018).

\section{Material and methods}

\subsection{Sample collection}

Sampling was performed during the research cruise POS466 of RV Poseidon, between 5th and 17th of March 2014, in the scope of the project MAPS- Madeira Archipelago Pre-Seamount Stages. Seawater samples, between the depths of 10 and $150 \mathrm{~m}$, were collected from 37 stations around the Madeira archipelago (Fig. 1, Table 1). The water column was sampled for physical, biological and chemical data, using a Seabird CTD (SBE911 plus), mounted on a Seabird SBE32 carousel equipped with 12 Niskin bottles of $10 \mathrm{~L}$ volume.

\subsection{Physical parameters}

In situ temperature and conductivity were measured with the Seabird CTD (SBE911 plus), with accuracies of $0.001{ }^{\circ} \mathrm{C}$ for temperature and $0.0003 \mathrm{~S} \mathrm{~m}^{-1}$ for conductivity. Practical salinity was converted from temperature, conductivity and depth measurements.

Fluorescence was measured with a Dr. Haardt BackScat II sensor with a sensitivity of $0.02 \mathrm{mg} \mathrm{m}^{-3}$. At shallow stations additionally, a Turner Cyclops- $7^{\mathrm{TM}}$ was used with a sensitivity of $0.03 \mathrm{mg} \mathrm{m}^{-3}$.

All raw CTD data were pre-processed following the GO-SHIP guidelines for the SBE 911plus, using the SBE-Data-Processing software (e.g. McTaggart et al., 2010). Visualization of the physical data was done using Ocean Data View software (Schlitzer, 2018).

\subsection{Satellite derived data}

Sea Surface Temperature (SST) products were processed at the Instituto di Scienze dell'Atmosfera e del Clima - Gruppo di Oceanografia da Satellite (ISAC-GOS). These products are based on the night-time images collected by infrared sensors mounted on different satellite platforms, and cover the Southern European Seas, including the eastern Atlantic Ocean and Black Sea. The ISAC-GOS processing tools include several algorithms for data extraction and preliminary quality control, cloudy pixel removal, ultra-high spatial resolution $(1 \mathrm{~km})$ and satellite image merging (Buongiorno Nardelli et al., 2013). The SST-L4 post-processed product used in this work has a daily temporal step. Chlorophyll- $a$ (Chla) data is an agglomeration of optical images collected by different satellites (MODIS and VIIRS). Chl- $a$ data was pre-processed by Plymouth Marine Laboratory Remote Sensing Group and has a horizontal resolution of $1 \mathrm{~km}$ with weekly averages. Although there is a daily Chl- $a$ product, the delayed time data used in this work offers better general quality. The algorithms used to process the data are documented in McClain et al. (1995) and Smyth et al. (2006) (Fig. 2).

Atlantic Iberian Biscay Irish Ocean Physics Reanalysis data (IBIPhys) and Atlantic Iberian Biscay Irish Ocean Biogeochemical Reanalysis data (IBI-Bio) were computed by Puertos del Estado in CESGA Supercomputing Facilities. The model code was developed by Mercator Ocean with the objective to produce a high resolution shortterm forecast for the physical and biogeochemical variables, surface currents, chlorophyll and nitrate, as a complementary framework for interpreting the influence of environmental variability on the coccolithophore distribution. IBI-Phys data has a daily resolution and IBI-Bio has a monthly resolution. Both models have a horizontal resolution of about $9 \mathrm{~km}\left(0.083^{\circ}\right)$. More information about these models can be 


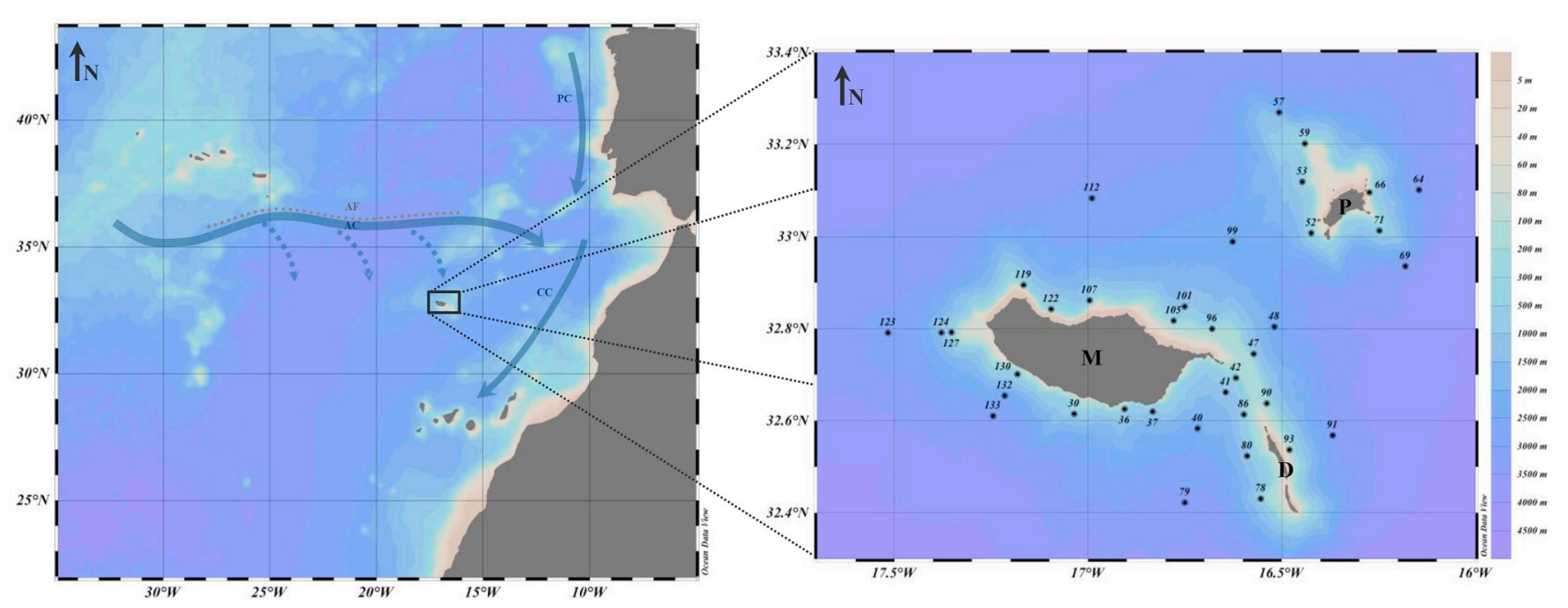

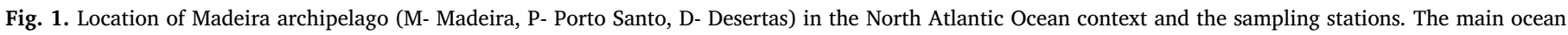

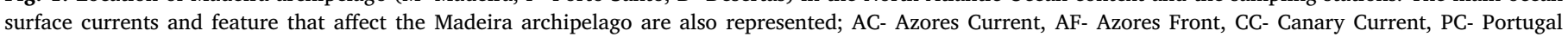
Current.

Table 1

Geographical coordinates, date and sampling depths of POS466 stations.

\begin{tabular}{|c|c|c|c|c|}
\hline Station & Latitude & Longitude & Date & Sampling depths (m) \\
\hline 30 & 32.615 & -17.036 & 05/03/2014 & $25,50,75,100,125$ \\
\hline 36 & 32.625 & -16.906 & $06 / 03 / 2014$ & $25,50,75,100$ \\
\hline 37 & 32.62 & -16.833 & 06/03/2014 & $25,50,75,100$ \\
\hline 40 & 32.583 & -16.717 & $06 / 03 / 2014$ & $10,25,50,100$ \\
\hline 41 & 32.662 & -16.645 & $06 / 03 / 2014$ & $10,25,50,100$ \\
\hline 42 & 32.693 & -16.618 & $06 / 03 / 2014$ & $10,25,50,75$ \\
\hline 47 & 32.732 & -16.582 & $07 / 03 / 2014$ & $25,50,100,150$ \\
\hline 48 & 32.804 & -16.519 & $07 / 03 / 2014$ & $10,75,100,125$ \\
\hline 52 & 33.007 & -16.424 & $07 / 03 / 2014$ & $25,75,100$ \\
\hline 53 & 33.119 & -16.447 & $07 / 03 / 2014$ & $10,25,50,100$ \\
\hline 57 & 33.269 & -16.507 & 08/03/2014 & $10,50,75,100$ \\
\hline 59 & 33.231 & -16.473 & 08/03/2014 & $25,50,100,150$ \\
\hline 64 & 33.101 & -16.146 & $09 / 03 / 2014$ & $25,60,100,125$ \\
\hline 66 & 33.097 & -16.253 & 09/03/2014 & $15,35,75,120$ \\
\hline 69 & 32.935 & -16.181 & $09 / 03 / 2014$ & $25,45,75,125$ \\
\hline 71 & 32.993 & -16.231 & $09 / 03 / 2014$ & $25,50,75,100$ \\
\hline 78 & 32.431 & -16.554 & $10 / 03 / 2014$ & $10,30,50,70$ \\
\hline 79 & 32.422 & -16.75 & $10 / 03 / 2014$ & $20,50,75,120$ \\
\hline 80 & 32.523 & -16.589 & $11 / 03 / 2014$ & $20,50,80,120$ \\
\hline 86 & 32.613 & -16.598 & $12 / 03 / 2014$ & $10,50,100$ \\
\hline 90 & 32.638 & -16.539 & $12 / 03 / 2014$ & $25,50,75,100$ \\
\hline 91 & 32.568 & -16.368 & $12 / 03 / 2014$ & $10,50,75,100,150$ \\
\hline 93 & 32.543 & -16.459 & $12 / 03 / 2014$ & $25,75,100,125$ \\
\hline 96 & 32.799 & -16.68 & $13 / 03 / 2014$ & $10,30,50,100,150$ \\
\hline 99 & 32.989 & -16.627 & $13 / 03 / 2014$ & $20,40,80$ \\
\hline 101 & 32.848 & -16.75 & $14 / 03 / 2014$ & $25,60,75,100$ \\
\hline 105 & 32.817 & -16.779 & $14 / 03 / 2014$ & $20,50,75$ \\
\hline 107 & 32.861 & -16.996 & $14 / 03 / 2014$ & $35,50,75,100$ \\
\hline 112 & 33.083 & -16.99 & $14 / 03 / 2014$ & $20,40,80$ \\
\hline 119 & 32.908 & -17.156 & $15 / 03 / 2014$ & $25,50,75,100$ \\
\hline 122 & 32.842 & -17.095 & $15 / 03 / 2014$ & $25,50,75,100$ \\
\hline 123 & 32.791 & -17.517 & $15 / 03 / 2014$ & $20,40,80$ \\
\hline 124 & 32.791 & -17.379 & $15 / 03 / 2014$ & $25,60,100,135$ \\
\hline 127 & 32.792 & -17.353 & $16 / 03 / 2014$ & $20,40,80$ \\
\hline 130 & 32.701 & -17.182 & $16 / 03 / 2014$ & $25,50,75,100$ \\
\hline 132 & 32.685 & -17.191 & $16 / 03 / 2014$ & 25 \\
\hline 133 & 32.654 & -17.215 & $16 / 03 / 2014$ & $25,50,75,100$ \\
\hline
\end{tabular}

found in Sotillo et al. (2015).

\subsection{Coccolithophores}

A total of 142 water samples were recovered for identification and quantification of coccolithophores. 2.5-4.0 L of seawater were filtered onboard through Whatman nuclepore track-etched polycarbonate membranes $(0.4 \mu \mathrm{m}$ pore size, $47 \mathrm{~mm}$ diameter $)$, using low vacuum suction ( $\sim 200$ mbar). Each filter was rapidly rinsed with enough distilled water to prevent salt precipitation, and left to dry in petri dishes at room temperature. At the lab, a randomly chosen angular sector (20$30^{\circ}$ ) of each filter was cut and permanently mounted on a slide using Entellan mounting media. Coccospheres were identified and counted under polarized light microscope (Leitz Ortholux II Pol-BK) at $1250 \times$ magnification. At least 400 coccospheres were counted through random fields of view along the radius of the filter, corresponding to areas between 3 and $7 \mathrm{~mm}^{2}$ of the filter screened. The absolute abundances (Coccosphere $\mathrm{L}^{-1}$ ) were estimated as follows:

Coccosphere $\mathrm{L}^{-1}=[N \mathrm{x}(T A / E A)] / V$. Where $N$ refers to the number of counted coccospheres in the examined area, $T A$ is the total filter area, $E A$ the examined area and $V$ the volume of filtered water.

Identification of coccolithophores was performed according to Cros and Fortuño (2002), Young et al. (2003), Jordan et al. (2004) and Frada et al. (2010). Small Gephyrocapsa group includes the Gephyrocapsa specimens smaller than $3 \mu \mathrm{m}$, such as G. aperta and G. ericsonii (Flores et al., 1999).

To estimate the diversity of the coccolithophore assemblage, the Margalef diversity index (Margalef, 1968) for each sample was calculated according to the formula $D_{\mathrm{Mg}}=(S-1) / \ln N$, where $S$ is the number of species and $N$ is the total number of individuals.

\subsection{Statistical analysis}

In order to test the normality of our data, the Shapiro-Wilk test of Normality was applied to temperature, salinity and total cell density values, recorded on two different sampling domains, NE and SW. For the separation of the 2 domains the temperature threshold of $17.6^{\circ} \mathrm{C}$ at $50 \mathrm{~m}$ depth was used. The (dis)similarity between these two geographic domains was then evaluated for each variable data set, using the $t$-test and the Monte Carlo permutation method. All these tools were included in the software package PAleontological STatistics (PAST) vers. 3.1 (Hammer et al., 2001). The multivariate technique Canonical Correspondence Analysis (CCA) was subsequently performed to evaluate the ecological similarities among coccolithophore taxa and their relationship with the environmental conditions. The same software package was used upon a data matrix composed by the samples as rows and 13 variables as columns (depth, temperature, salinity, fluorescence, Margalef diversity, total coccolithophore cell densities and the cell densities of the most common seven taxa). 

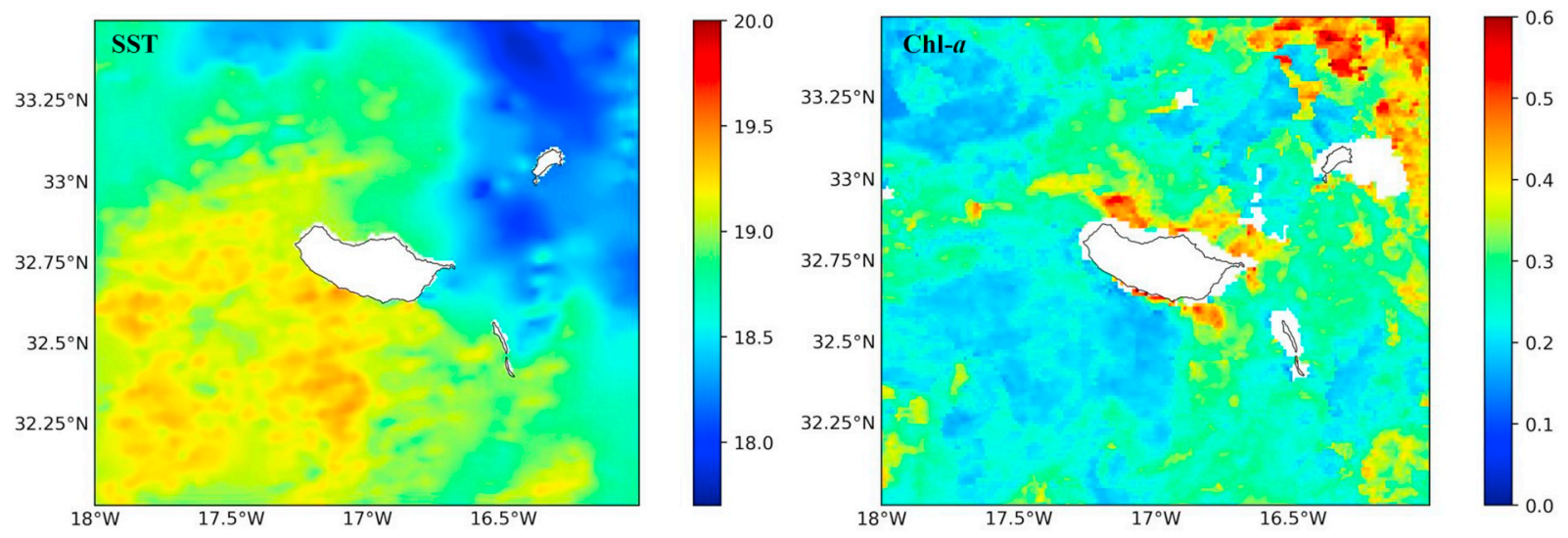

Fig. 2. Satellite derived maps of SST and Chl- $a$ based on 15.03.2014 and 06.03.2014, respectively.

\section{Results}

\subsection{Physical parameters}

Sea Surface Temperature was a relatively stable environmental parameter across the entire Madeira archipelago, with a gradient of increasing values from $\mathrm{NE}$ towards $\mathrm{SW}$. At $50 \mathrm{~m}$ water depth, temperature reached the lowest values (around $17.2^{\circ} \mathrm{C}$ ) between Madeira and Porto Santo islands and the highest $\left(18.1^{\circ} \mathrm{C}\right)$ at the southwest coast of Madeira island. At a similar depth, salinity revealed a comparable trend across the sampling transects (36.5 in NE vs. 36.7 at SW) (Fig. 3). The representation of temperature and salinity at the $50 \mathrm{~m}$ depth was chosen based on the highest cell abundances around this depth layer (compare section 4.2.1 and Fig. 6).

Phytoplankton biomass, inferred from fluorescence, showed the highest values at NE of Madeira island and east of Desertas islands (Fig. 4). The map is based on integrated data, since the biological growth occurred inside a well-mixed oceanic layer.

\subsection{Species diversity and cell density of the total coccolithophores}

Coccolithophores were well represented in the samples confirming the oligotrophic character of the area. A total of 35 distinct heterococcolith taxa (4 genera and 31 species) were recognized using polarizing light microscopy. An additional preliminary Scanning Electron Microscopy (SEM) analysis revealed more five Syracosphaera species. The complete list of taxa, including the rare specimens, can be found in Appendix A. Selected taxa are illustrated in Plate 1.

Total cell densities ranged between $12 \times 10^{3}$ and $112 \times 10^{3}$ cell $\mathrm{L}^{-1}$, being Emiliana huxleyi (dominated by the morphotype type A) the principal species followed by small Gephyrocapsa, together with relative

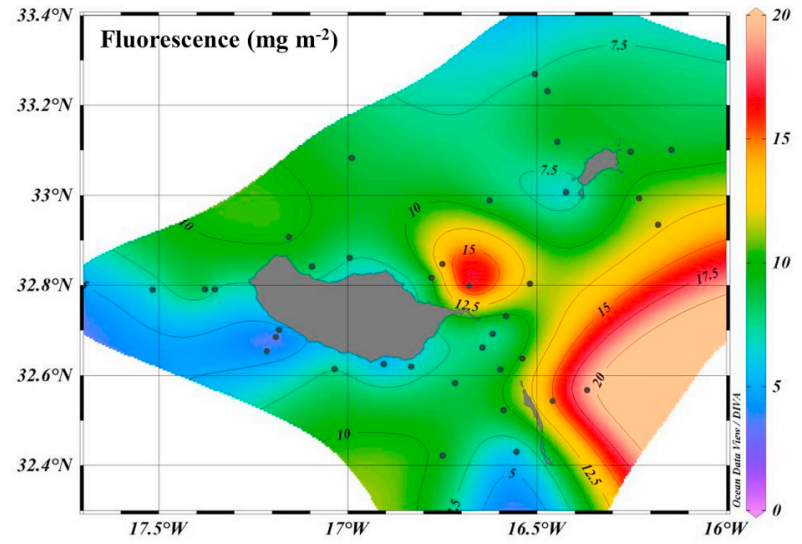

Fig. 4. Spatial distribution of the integrated fluorescence data.

abundances between 77 and $98 \%$ per sample. The most common (with relative abundances $>2 \%$ in at least two samples) subordinate taxa, in order of decreasing abundance, were: Gephyrocapsa oceanica, Michaelsarsia spp., Syracosphaera spp., Umbilicosphaera spp. and Algirosphaera robusta (Table 2). The absolute abundances of these coccolithophores per sample can be consulted in Appendix B.

In order to recognize the spatial distribution of coccolithophores around Madeira archipelago, total cell integrated abundances over the water column $(0-150 \mathrm{~m})$ and the most common taxa were plotted (Fig. 5). The highest total cell densities, mainly determined by the dominant E. huxleyi, were observed off the northeast coast of Madeira and south of Porto Santo, and the lowest cell densities off the southwest coast of Madeira island. A similar pattern was observed for small
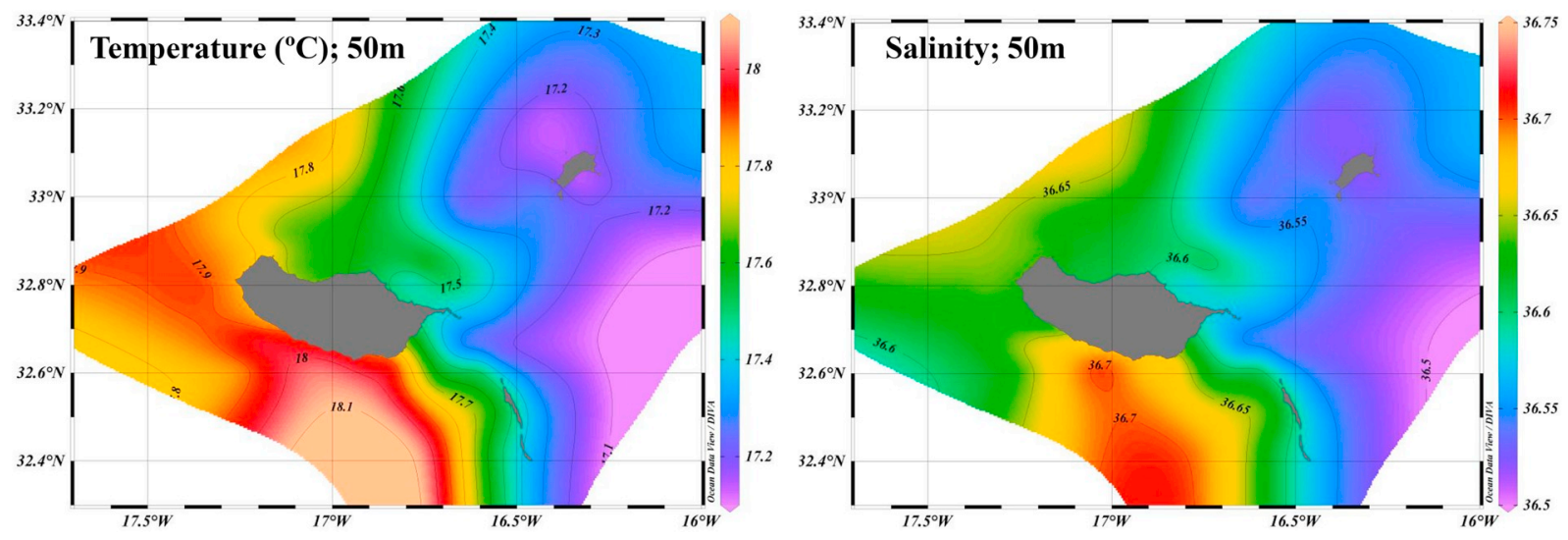

Fig. 3. Isosurface map of temperature and salinity for a depth of $50 \mathrm{~m}$, showing its spatial distribution around the Madeira archipelago. 
Table 2

Mean and maximum cell densities (cell $\mathrm{L}^{-1}$ ) of the coccolithophore taxa observed during the sampling period. Minima and maxima values of the total coccolithophores and the parameters temperature, salinity and fluorescence are also indicated.

\begin{tabular}{|c|c|c|c|c|c|}
\hline \multirow[t]{2}{*}{ Taxa } & \multicolumn{2}{|l|}{ Cell L ${ }^{-1}$} & \multicolumn{3}{|c|}{ Physical Parameters } \\
\hline & Mean & Max & & Min & Max \\
\hline Acanthoica spp. & 7.99 & 122.67 & $\begin{array}{l}\text { Temperature } \\
\left({ }^{\circ} \mathrm{C}\right)\end{array}$ & 17.04 & 18.18 \\
\hline Algirosphaera robusta & 268.15 & 1927.62 & Salinity & 36.50 & 36.71 \\
\hline Alisphaera spp. & 9.18 & 260.99 & $\begin{array}{l}\text { Fluorescence } \\
\left(\mathrm{mg} \mathrm{m}^{-3}\right)\end{array}$ & 0.04 & 0.26 \\
\hline Alveosphaera spp. & 19.26 & 187.76 & & & \\
\hline Calcidiscus leptoporus & 166.38 & 628.11 & & & \\
\hline Calciosolenia spp. & 109.02 & 613.33 & & & \\
\hline Ceratolithus cristatus & 1.63 & 73.14 & & & \\
\hline $\begin{array}{l}\text { Coronosphaera } \\
\text { mediterranea }\end{array}$ & 64.72 & 515.20 & & & \\
\hline Discosphaera tubifera & 49.68 & 306.67 & & & \\
\hline Emiliania huxleyi & 28122.88 & 63512.28 & & & \\
\hline Florisphaera profunda & 2.05 & 80.00 & & & \\
\hline Small Gephyrocapsa & 14019.09 & 76718.12 & & & \\
\hline Gephyrocapsa muellerae & 41.70 & 394.95 & & & \\
\hline Gephyrocapsa oceanica & 435.65 & 1664.76 & & & \\
\hline Helicosphaera spp. & 57.10 & 418.18 & & & \\
\hline Ophiaster spp. & 19.88 & 136.30 & & & \\
\hline Pontosphaera spp. & 0.62 & 87.62 & & & \\
\hline Michaelsarsia spp. & 722.75 & 2341.82 & & & \\
\hline Rhabdosphaera spp. & 6.72 & 146.03 & & & \\
\hline Scyphosphaera apsteinii & 9.63 & 136.30 & & & \\
\hline Syracosphaera spp. & 346.61 & 985.71 & & & \\
\hline Umbellosphaera tenuis & 1.06 & 76.67 & & & \\
\hline Umbilicosphaera spp. & 331.64 & 960.00 & & & \\
\hline \multirow[t]{2}{*}{ Holococcolithophores } & 38.25 & 368.00 & & & \\
\hline & Min & $\operatorname{Max}$ & & & \\
\hline $\begin{array}{l}\text { Total coccospheres } \\
\quad\left(\text { cell } \mathrm{L}^{-1} \text { ) }\right.\end{array}$ & 12796.40 & 112762.00 & & & \\
\hline
\end{tabular}

Gephyrocapsa, although its highest abundances were observed north of Ponta de S. Lourenço, the only site where small Gephyrocapsa cell density exceeded those of E. huxleyi. G. oceanica showed the highest cell densities closer to the south coast of Madeira island and further south, as well as at NW and NE of this island. The pattern associated to A. robusta revealed greater abundances in one site located at the northwest coast of Madeira island and relevant densities towards the southeast. Concerning Michaelsarsia spp., the highest abundances were found in a quite disperse area in the NW, NE and SE of Madeira island and south of Porto Santo. Syracosphaera spp. and Umbilicosphaera spp. showed a significant presence even more homogeneous with the highest densities distributed throughout the archipelago.

Table 3 shows the average of the total cell counts for the two geographic domains, as well as the average of the densities, integrated over the water column, for the 7 most abundant species. Average of Margalef diversity index for both domains is also indicated. Total cell abundances, as well as abundances of E. huxleyi and small Gephyrocapsa showed higher values in the NE domain, whereas the opposite was observed for $G$. oceanica and A. robusta. The other taxa had a more homogenous spatial distribution.

\subsubsection{Vertical distribution of coccolithophore taxa}

The vertical distribution of the main coccolithophores is presented together with a selection of less abundant taxa (Fig. 6). Information of the mean and maximum densities of the less frequent and rare taxa are also given in Table 2. The dominant taxa E. huxleyi and small Gephyrocapsa revealed a roughly uniform vertical distribution, although the latter presented a peak at $60 \mathrm{~m}$. Other taxa, such as Alveosphaera spp., G. muellerae, G. oceanica, C. leptoporus, Calciosolenia spp., C. mediterranea, Helicosphaera spp., Michaelsarsia spp. and Syphosphaera apsteinii revealed higher cell densities down to $75 \mathrm{~m}$. However, G. oceanica and C. leptoporus still showed significant abundances throughout the $150 \mathrm{~m}$ sampled water column. A. robusta was recorded from the surface to deeper $(125 \mathrm{~m})$ waters, with an important peak at $50 \mathrm{~m}$. The presence of $D$. tubifera was also roughly homogeneous down to $125 \mathrm{~m}$, with the major abundances at 60 and $75 \mathrm{~m}$. Ophiaster spp. showed some importance at the depths of 50, 75 and $150 \mathrm{~m}$. The Syracosphaera group was moderately represented along all depths, although with a trend to major abundances down to $60 \mathrm{~m}$. Umbilicosphaera spp. was also present all over the sampling depths, but with a tendency for higher densities at 75 and $50 \mathrm{~m}$. In relation to the rare forms, the maximum abundances of Alisphaera spp. and Rhabdosphaera spp. at $50 \mathrm{~m}$ has to be emphasized.

\subsection{Statistical analysis}

For all tested variables the Shapiro-Wilk values (Table 4) are higher than the probability $\alpha=0.05$ so, for this level of significance, the null hypothesis $\left(\mathrm{H}_{0}\right.$ : the data is normally distributed) is retained; i.e., normality can be assumed for all variable data sets. Values obtained by $t$ test (Table 5) are higher than the critical value (for $\alpha=0.05$ ) so, the null hypothesis $\left(\mathrm{H}_{0}\right.$ : the data sets from the two domains could be retrieved from the same population means are similar) must be rejected; i.e. the three variable data sets are statistically distinct.

\subsubsection{Canonical Correspondence Analysis}

The two first components of CCA explained $98 \%$ of total data variability, with the first component (CCA1) containing $78.1 \%$ and the second (CCA2) $19.9 \%$ of the total information (Fig. 7). The eigenvalues and its percentage variance are depicted in Table 6 whereas the scores of each variable can be consulted in Table 7 . Environmental variables and the direction of its maximum change are indicated by vectors, which length is proportional to the rate of change among samples. CCA1 is mostly represented by temperature and salinity, showing a gradient between colder and less saline waters (negative loadings) and warmer and more saline ones (positive loadings), thus reflecting the presence of a thermohaline front in the region. Depth is also correlated with CCA1, negatively in this case, but in a lesser extent. Fluorescence shows a moderate negative correlation with CCA2. In the ordination diagram for the sample scores (a), the position of the SW cluster on the right side of CCA1 is prominent, associated with increases in temperature and salinity. On the other hand, the NE cluster is in an opposite position, associated with colder and less saline waters. Samples from all depths represented on both sides of this axis are observed, perhaps reflecting the weakness of the variable depth in the analyzed sample set. Concerning the axis CCA2, the SW cluster is mostly on the positive side, opposite to fluorescence increase, whereas the NE cluster is mainly positioned on the negative side, in the direction of increasing fluorescence. Furthermore, there are also more dots (both domains) on the negative side of this axis, meaning that the samples from depths around $50 \mathrm{~m}$ correspond to the most productive layers. The ordination diagram for biological data (b) shows a strong negative correlation between the total cell densities, as well as E. huxleyi, with the temperature and salinity. On the other hand, the Syracosphaera group, $G$. oceanica, small Gephyrocapsa and Michaelsarsia spp. seem to be associated with warmer and more saline waters. CCA2 shows an opposition between the primary productivity, given by the direction of increasing fluorescence, and the Margalef diversity, indicating that the richest samples are not the most diversified. A. robusta, G. oceanica and Umbilicosphaera spp., with positive loadings, are also in opposition to fluorescence.

\section{Discussion}

5.1. General patterns in the coccolithophore abundances around Madeira archipelago

Previous investigations on coccolithophores at Madeira island were 

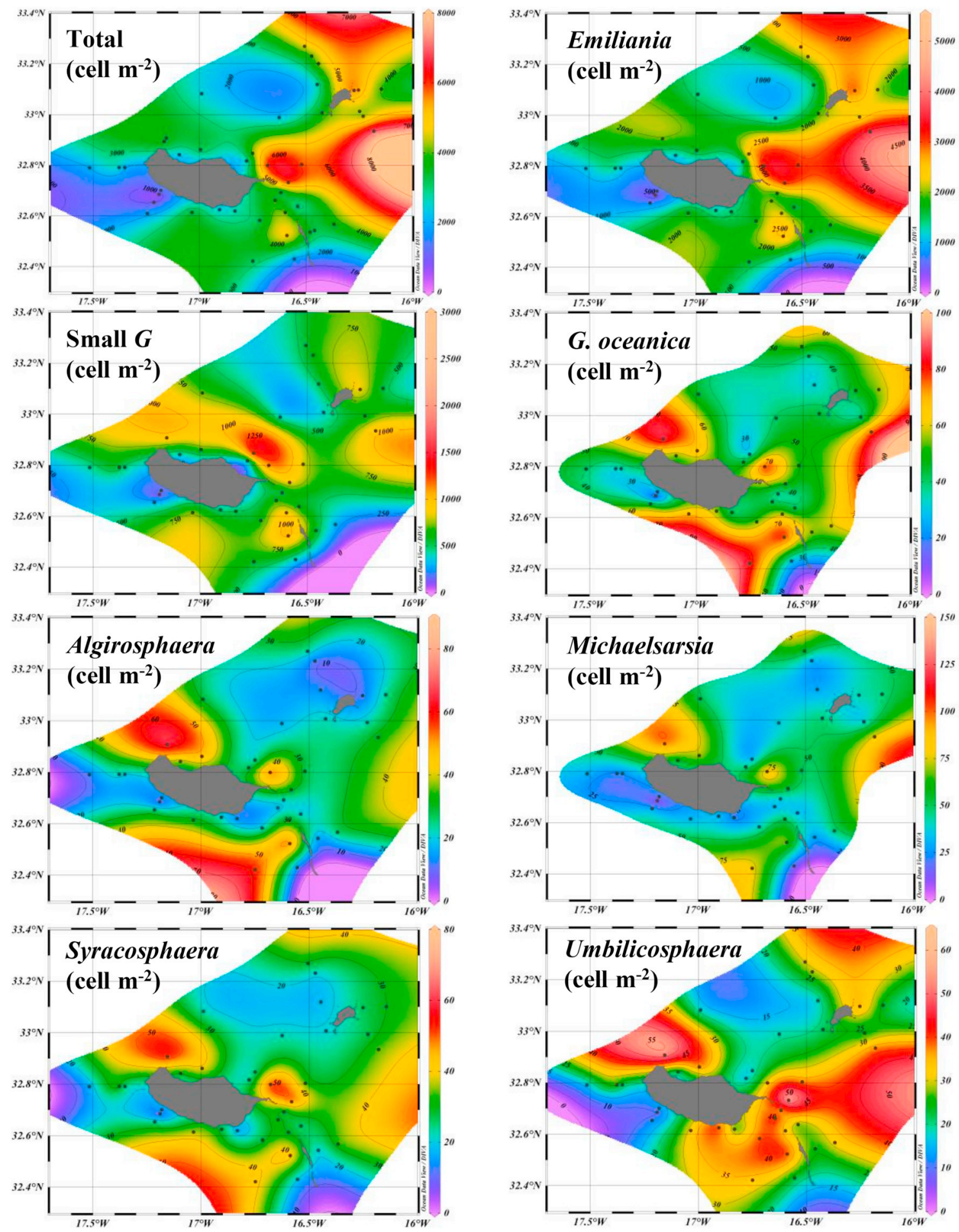

Fig. 5. Spatial distribution of the total cell densities and of the most common coccolithophore taxa based on its integrated data.

developed by Kaufmann (2004) and Kaufmann et al. (2015), representing data from the south coast of this island. The present work significantly expands the knowledge on the abundance, distribution and variability in coccolithophores around the whole Madeira archipelago. It also confirms the coccolithophore biodiversity reported by Kaufmann et al. (2015) for the region, based on detailed taxonomic studies using SEM. Of the 23 identified genera in the present study, 20 are common to previous work and 3 are new.

The highest total coccolithophore densities were observed off the northeast coast of Madeira and south of Porto Santo, whereas the lowest cell densities were recorded off the southwest coast of Madeira island (Fig. 5). The higher productivity spots are strongly correlated with the fluorescence signals (Fig. 4) and are well illustrated in the modelled Chl- $a$ and nitrate concentrations for the sampling period, one of the most relevant macronutrient for coccolithophores (Barcelos e Ramos et al., 2017) (Fig. 8). The spatial variability of the total cell densities in the CCA (Fig. 7) reflects its strong negative correlation with temperature and salinity. This opposition may associate the higher productivity spots with the presence of a frontal zone characterized by well-mixed, colder and less saline water masses. 


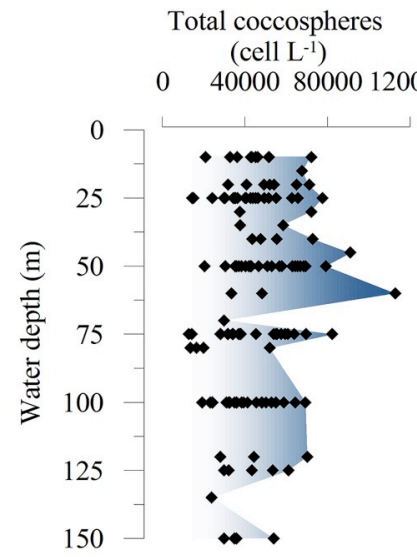

Acantoica spp.

(cell L-1)

0

100

$200 \quad 0$

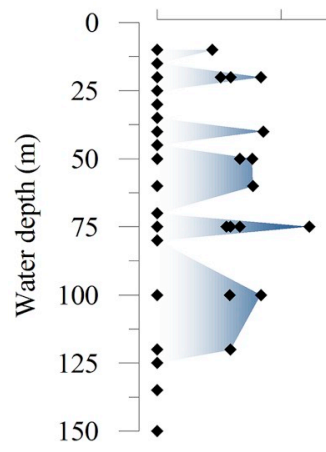

Calciosolenia spp.

(cell $\mathrm{L}^{-1}$ )

$0 \quad 400$

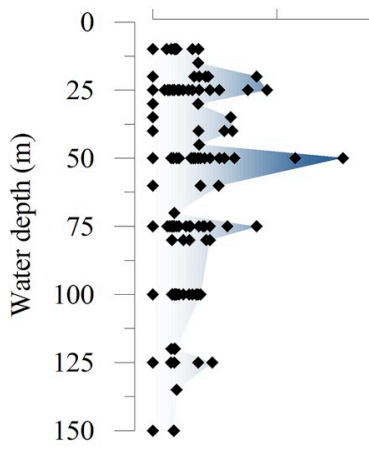

Michaelsarcia spp.

(cell L-1)

1500

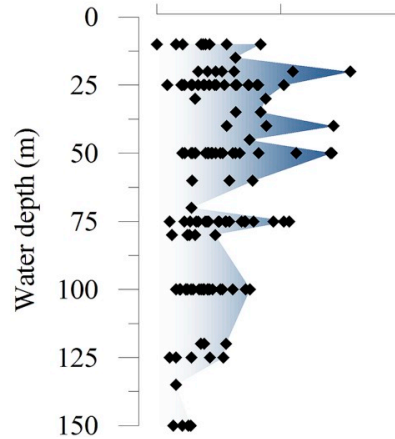

$800 \quad 0$

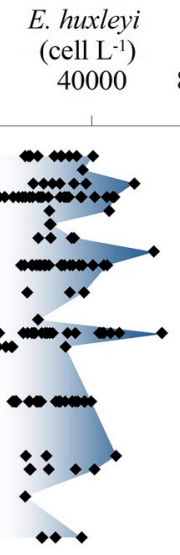

A. robusta

(cell L-1) 1000
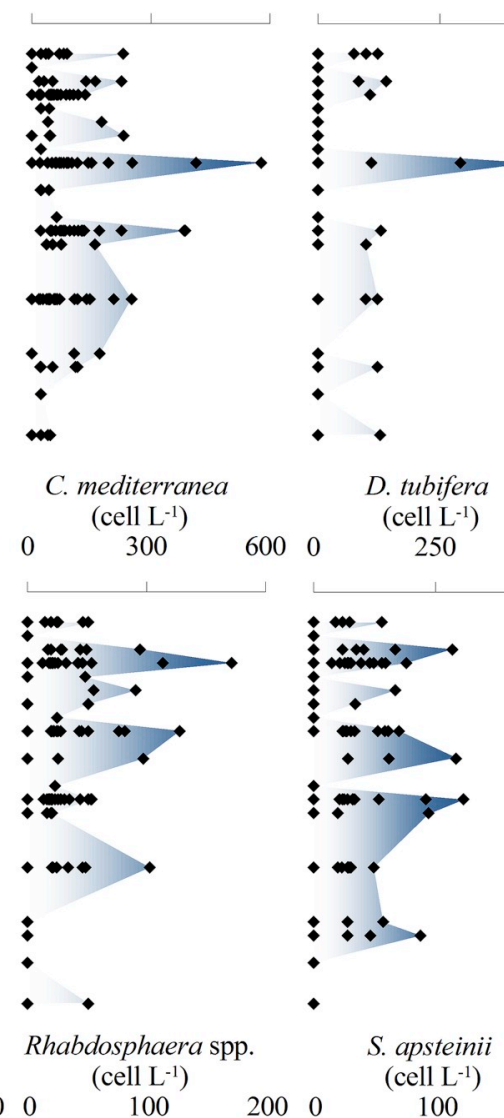

500
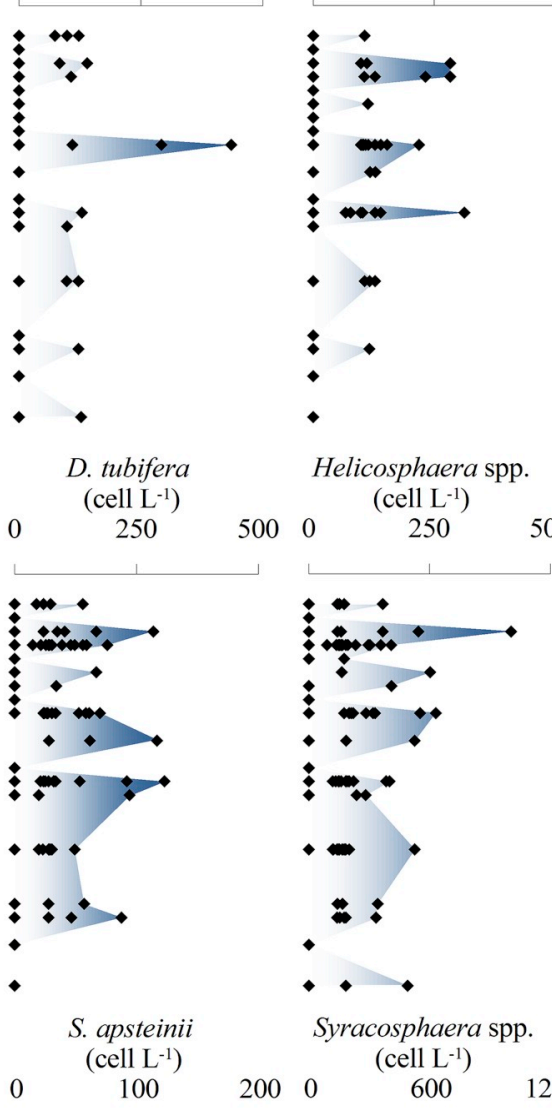

Syracosphaera spp.
$($ cell L-1)

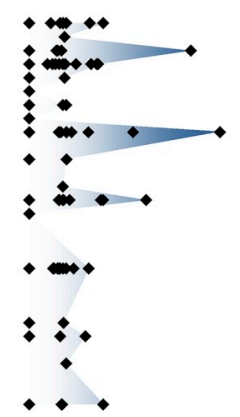

Alveosphaera spp.
(cell L-1) 3000

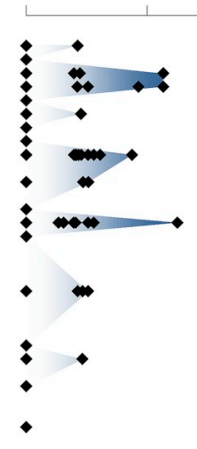

Helicosphaera spp. $($ cell L-1)
250
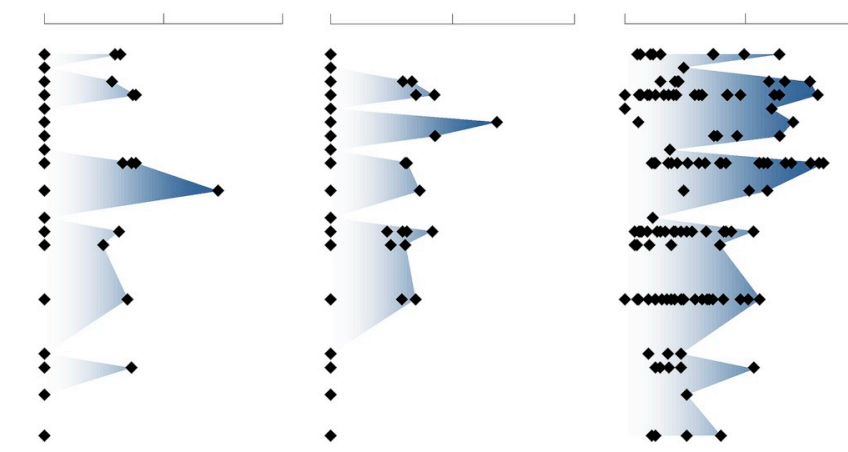

G. oceanica (cell L-1)

2000

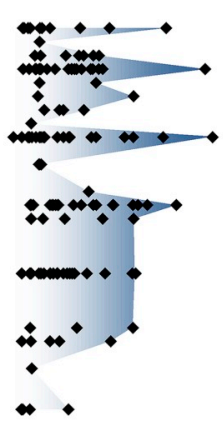

C. leptoporus (cell L-1)

$\begin{array}{lrl}3000 & 500 \quad 1000\end{array}$

Fig. 6. Vertical distribution of the coccolithophore taxa observed during the sampling period along the uppermost $150 \mathrm{~m}$ water depth. 
Table 4

Values for the Shapiro-Wilk test of Normality.

\begin{tabular}{ll}
\hline Variables & $W$ \\
\hline Temperature $_{(\mathrm{NE})}$ & 0.82 \\
Temperature $_{(\mathrm{SW})}$ & 0.95 \\
Salinity $_{(\mathrm{NE})}$ & 0.77 \\
Salinity $_{(\mathrm{SW})}$ & 0.92 \\
Total cells $_{(\mathrm{NE})}$ & 0.95 \\
Total cells $_{(\mathrm{SW})}$ & 0.97 \\
\hline
\end{tabular}

Previous works have already mentioned the presence of a subtropical front at the Madeira island latitude (Siedler et al., 1985; Caldeira et al., 2002), as well as the temperature difference between the north and south coasts of Madeira (Caldeira et al., 2002). This oceanographic feature, which dynamic varies throughout the year, may be explained by a westerly incoming flow in the Madeira waters, referred by some authors as a branch of the Azores Current (e.g. Käse and Siedler, 1982; Cromwell and Challengor, 1996; Pingree et al., 1999). The map of surface currents for the studied region (Fig. 9) corroborates the injection of this westerly flow with potential to influence the water masses of the Madeira region. As a consequence, temperature and salinity gradients from NE to SW were generated, which is clearly visible in the recorded data (Figs. 2 and 3). The T-S diagram (Fig. 10) and Table 8 show the differences between the water masses of these two geographic domains. The distribution of samples in two clusters in the ordination diagram confirms this difference. Furthermore, the average of the total cell abundances, as well as of E. huxleyi and small Gephyrocapsa showed higher values in the NE domain, whereas G. oceanica and A. robusta dominated in the SW sector. The average of Margalef diversity index was slightly higher at SW, where the productivity was lower (Table 3 ).

Despite this difference, a well-mixed surface layer (0-150 m) (Fig. 10b) was observed all over the region during the sampling period, typical for winter, beginning spring (Waniek, 2003). The weak relation between the samples and the variable depth in the CCA reflects the absence of water column stratification. Due to this feature, no vertical succession of specific, depth related coccolithophore assemblages (Winter et al., 1994) was detected during the present study. This vertical zonation within the photic zone is typical of the summer months with highly stratified surface layer around the Madeira archipelago (own unpublished data) and in the surroundings seamounts (Vilas et al., 2009; own unpublished data).

\subsection{Coccolithophore ecology and potential as proxies for environmental conditions}

Emiliania huxleyi, together with small Gephyrocapsa group, were the dominant taxa in the coccolithophore assemblage. E. huxleyi is known as the best indicator of productive water mass conditions, being highly associated with upwelling regimes (e.g. Silva et al., 2009; Guerreiro et al., 2013; Narciso et al., 2016; Ausín et al., 2018). The opportunistic E. huxleyi is also referred as the dominant species of the coccolithophore assemblage in other oceanographic contexts of the NE Atlantic. For instance, maximum cell densities of $E$. huxleyi occurred in the northernmost stations $\left(45^{\circ} \mathrm{N}-47^{\circ} \mathrm{N}\right)$ of an open-ocean transect, associated with well-mixed and high-nutrient conditions, whereas in the southernmost stations $\left(33^{\circ} \mathrm{N}-35^{\circ} \mathrm{N}\right)$, where the oligotrophic and well-stratified water masses are present, this species is also dominant (Schiebel et al., 2011). Small Gephyrocapsa, namely G. ericsonii, shows ecological demands similar to those of E. huxleyi (Haidar and

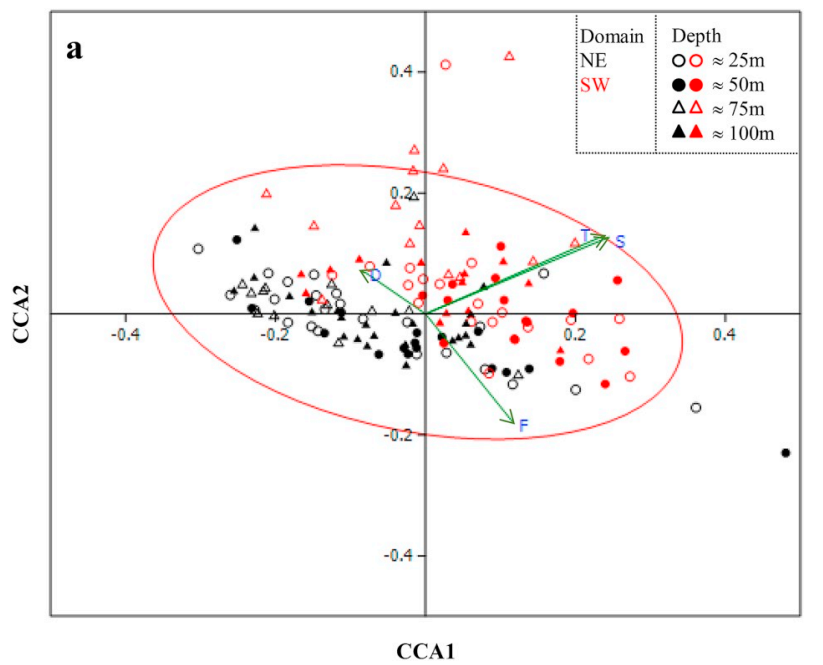

Fig. 7. CCA ordination biplots conducted on the POS466 data set for the 142 samples (a) and for the coccolithophore data (b). Environmental variables are indicated by green vectors; D-depth, F- fluorescence, S- salinity, T-temperature. The ellipse defines the region that contains $95 \%$ of all samples. Samples are marked by colored symbols according to their sampling domain and depth. (For interpretation of the references to color in this figure legend, the reader is referred to the Web version of this article.)

Table 6

Eigenvalues and respective percentage of the two first CCA axis performed in the coccolithophore assemblages in the vicinity of Madeira archipelago.

\begin{tabular}{lll}
\hline CCA & Eigenvalue & $\%$ \\
\hline 1 & 0.0049 & 78.1 \\
2 & 0.0012 & 19.9 \\
\hline
\end{tabular}

Thierstein, 2001), being its affinity to conditions with high nutrient content mentioned in numerous studies (e.g. Baumann et al., 2008; Silva et al., 2008; Narciso et al., 2016). Ausín et al. (2018) also associated small Gephyrocapsa with the early stages of an upwelling event, with colder waters and higher nutrient availability than the upwelling relaxation stage, dominated by E. huxleyi. The highest E. huxleyi and small Gephyrocapsa cell densities, which in turn represent the highest abundant samples, were observed off the northeast coast of Madeira and south of Porto Santo (Fig. 5). As mentioned above, these higher productivity spots are positively correlated with the fluorescence (Fig. 4), modelled Chl- $a$ and nitrate concentrations (Figs. 2 and 3), and negatively correlated with the temperature and salinity. Observations corroborate the already known ecological preferences of these taxa, particularly for E. huxleyi, i.e., well-mixed colder and less saline water masses, with high nutrient content. This pattern is less evident for small Gephyrocapsa that continues to defy our understanding of its ecological demands.

An extensive mixed surface layer led to the supply of nutrients from deeper levels to shallower ones in the photic zone. While it promoted the development of the upper photic zone (UPZ) taxa, this deepening in the nutricline also explains the almost absence of $F$. profunda, a typical low photic zone (LPZ) species from low-latitude regions (Okada and Honjo, 1973; Okada and McIntyre, 1977; Winter and Siesser, 1994), not only in the

Table 5

$t$-test of the means.

\begin{tabular}{|c|c|c|c|}
\hline Variables (domain) & $\mathrm{t}$-test & critical value $(\alpha=0.05)$ & Monte Carlo (10,000 permut.) \\
\hline Temp. (NE) $v s$ Temp. (sW) & 10.077 & 2.0301 & 0.0001 \\
\hline Sal. (NE) vs Sal. (SW) & 9.684 & & 0.0001 \\
\hline T.cells ${ }_{(\mathrm{NE})} v s$ T.cells $(\mathrm{sW})$ & 3.716 & & 0.0008 \\
\hline
\end{tabular}


Table 7

Scores of the all variables obtained in the CCA analysis performed in the coccolithophore assemblages in the vicinity of Madeira archipelago.

\begin{tabular}{|c|c|c|c|c|c|c|c|c|}
\hline Variables & CCA1 & CCA2 & Variables & CCA1 & CCA2 & Variables & CCA1 & CCA2 \\
\hline Depth & -0.16 & 0.14 & $53(100)$ & 0.04 & -0.04 & $93(100)$ & 0.05 & -0.01 \\
\hline Fluorescence & 0.23 & -0.36 & $57(10)$ & -0.15 & -0.02 & 93 (125) & 0.06 & -0.05 \\
\hline Salinity & 0.49 & 0.25 & $57(50)$ & -0.13 & -0.03 & $96(10)$ & 0.20 & -0.13 \\
\hline Temperature & 0.47 & 0.26 & $57(75)$ & -0.22 & 0.00 & $96(30)$ & -0.01 & -0.07 \\
\hline Total cells & 0.01 & 0.01 & $57(100)$ & -0.11 & 0.00 & $96(50)$ & 0.09 & -0.09 \\
\hline Margalef div. & 0.45 & 5.30 & $59(25)$ & -0.18 & 0.05 & $96(100)$ & -0.04 & 0.00 \\
\hline E. huxleyi & -1.05 & 0.10 & $59(50)$ & -0.01 & -0.06 & $96(150)$ & -0.26 & 0.04 \\
\hline Small G. & 1.79 & -0.78 & $59(100)$ & -0.18 & 0.03 & $99(20)$ & -0.11 & 0.02 \\
\hline G. oceanica & 4.19 & 11.64 & 59 (150) & -0.03 & -0.08 & $99(40)$ & 0.02 & -0.04 \\
\hline A. Robusta & 1.71 & 5.49 & $64(25)$ & -0.13 & 0.01 & $99(80)$ & -0.07 & 0.01 \\
\hline Michaelsarcia & 1.35 & -1.77 & $64(60)$ & -0.23 & 0.01 & $101(25)$ & 0.36 & -0.15 \\
\hline Syracosph. & 3.27 & 1.27 & 64 (100) & 0.06 & 0.00 & $101(60)$ & 0.48 & -0.23 \\
\hline Umbilicosph. & -0.54 & 5.61 & 64 (125) & -0.03 & -0.05 & $101(75)$ & 0.12 & -0.10 \\
\hline $30(25 \mathrm{~m})$ & 0.02 & 0.05 & $66(15)$ & 0.12 & -0.12 & $101(100)$ & -0.08 & -0.05 \\
\hline $30(50)$ & 0.09 & 0.06 & 66 (35) & -0.11 & 0.00 & $105(20)$ & -0.21 & 0.07 \\
\hline $30(75)$ & 0.14 & 0.09 & $66(75)$ & -0.12 & -0.05 & $105(50)$ & -0.16 & 0.02 \\
\hline $30(100)$ & 0.14 & 0.05 & $66(120)$ & -0.09 & -0.04 & $105(75)$ & -0.13 & 0.05 \\
\hline 30 (125) & 0.05 & 0.07 & $69(25)$ & 0.03 & -0.06 & 107 (35) & 0.26 & -0.01 \\
\hline $36(25)$ & 0.03 & 0.41 & 69 (45) & -0.06 & -0.07 & $107(50)$ & 0.26 & 0.06 \\
\hline $36(50)$ & 0.10 & 0.11 & $69(75)$ & -0.22 & 0.04 & $107(75)$ & -0.14 & 0.02 \\
\hline $36(75)$ & -0.04 & 0.18 & 69 (125) & -0.07 & -0.03 & $107(100)$ & 0.02 & -0.01 \\
\hline $36(100)$ & 0.05 & 0.05 & 71 (25) & -0.14 & -0.03 & $112(20)$ & 0.27 & -0.10 \\
\hline 37 (25) & -0.12 & 0.06 & $71(50)$ & -0.02 & -0.07 & $112(40)$ & 0.24 & -0.12 \\
\hline $37(50)$ & 0.03 & 0.02 & $71(75)$ & -0.23 & 0.04 & $112(80)$ & -0.01 & 0.15 \\
\hline 37 (75) & 0.03 & 0.07 & $71(100)$ & -0.11 & -0.04 & 119 (25) & 0.00 & 0.06 \\
\hline 37 (100) & 0.06 & 0.01 & $78(10)$ & 0.19 & -0.01 & $119(50)$ & 0.27 & -0.06 \\
\hline 40 (10) & 0.14 & -0.02 & 78 (30) & -0.07 & 0.08 & 119 (75) & 0.20 & 0.12 \\
\hline $40(25)$ & 0.10 & 0.00 & $78(50)$ & 0.10 & 0.02 & $119(100)$ & 0.18 & -0.06 \\
\hline $40(50)$ & 0.04 & 0.05 & $78(70)$ & -0.15 & 0.15 & $122(25)$ & 0.09 & -0.01 \\
\hline 40 (100) & -0.17 & 0.07 & 79 (20) & -0.02 & 0.05 & $122(50)$ & 0.02 & -0.05 \\
\hline $41(10)$ & -0.02 & -0.01 & 79 (50) & 0.20 & 0.00 & $122(75)$ & -0.02 & 0.12 \\
\hline $41(25)$ & -0.12 & 0.03 & 79 (75) & -0.02 & 0.24 & $122(100)$ & -0.13 & 0.07 \\
\hline $41(50)$ & -0.01 & -0.05 & 79 (120) & -0.01 & 0.09 & $123(20)$ & 0.08 & -0.10 \\
\hline $41(100)$ & -0.05 & 0.09 & $80(20)$ & 0.06 & -0.01 & $123(40)$ & 0.12 & -0.04 \\
\hline $42(10)$ & -0.08 & -0.01 & $80(50)$ & 0.13 & -0.01 & $123(80)$ & -0.21 & 0.20 \\
\hline $42(25)$ & -0.15 & 0.07 & $80(80)$ & 0.05 & 0.06 & $124(25)$ & 0.22 & -0.07 \\
\hline $42(50)$ & -0.01 & -0.03 & $80(120)$ & 0.10 & 0.09 & $124(60)$ & 0.12 & -0.04 \\
\hline $42(75)$ & -0.13 & 0.02 & $86(10)$ & 0.16 & 0.07 & $124(100)$ & 0.03 & 0.00 \\
\hline 47 (25) & -0.26 & 0.03 & $86(50)$ & 0.07 & -0.03 & 124 & -0.16 & 0.04 \\
\hline $47(50)$ & -0.03 & -0.06 & $86(100)$ & 0.05 & -0.03 & $127(20)$ & -0.01 & 0.02 \\
\hline 47 (100) & -0.15 & 0.00 & $90(25)$ & 0.07 & -0.02 & $127(40)$ & 0.18 & -0.08 \\
\hline 47 (150) & -0.08 & -0.02 & $90(50)$ & 0.14 & -0.09 & $127(80)$ & -0.01 & 0.27 \\
\hline $48(10)$ & -0.23 & 0.01 & $90(75)$ & -0.02 & 0.01 & $130(25)$ & -0.02 & 0.08 \\
\hline $48(75)$ & -0.20 & 0.00 & $90(100)$ & 0.08 & 0.05 & $130(50)$ & 0.00 & 0.03 \\
\hline 48 (100) & 0.04 & -0.04 & $91(10)$ & -0.30 & 0.11 & $130(75)$ & 0.02 & 0.24 \\
\hline 48 (125) & -0.02 & -0.01 & $91(50)$ & -0.25 & 0.12 & $130(100)$ & -0.09 & 0.09 \\
\hline $52(25)$ & -0.18 & -0.01 & $91(75)$ & -0.21 & 0.04 & $132(25)$ & 0.07 & 0.02 \\
\hline $52(75)$ & -0.24 & 0.05 & $91(100)$ & -0.23 & 0.06 & $133(25)$ & 0.06 & 0.08 \\
\hline $52(100)$ & -0.12 & 0.01 & 91 (150) & -0.23 & 0.14 & $133(50)$ & 0.14 & -0.01 \\
\hline $53(10)$ & 0.08 & -0.09 & $93(25)$ & -0.15 & 0.03 & 133 (75) & 0.11 & 0.43 \\
\hline $53(25)$ & -0.20 & 0.02 & $93(75)$ & -0.02 & 0.20 & $133(100)$ & 0.05 & 0.14 \\
\hline $53(50)$ & 0.11 & -0.10 & & & & & & \\
\hline
\end{tabular}
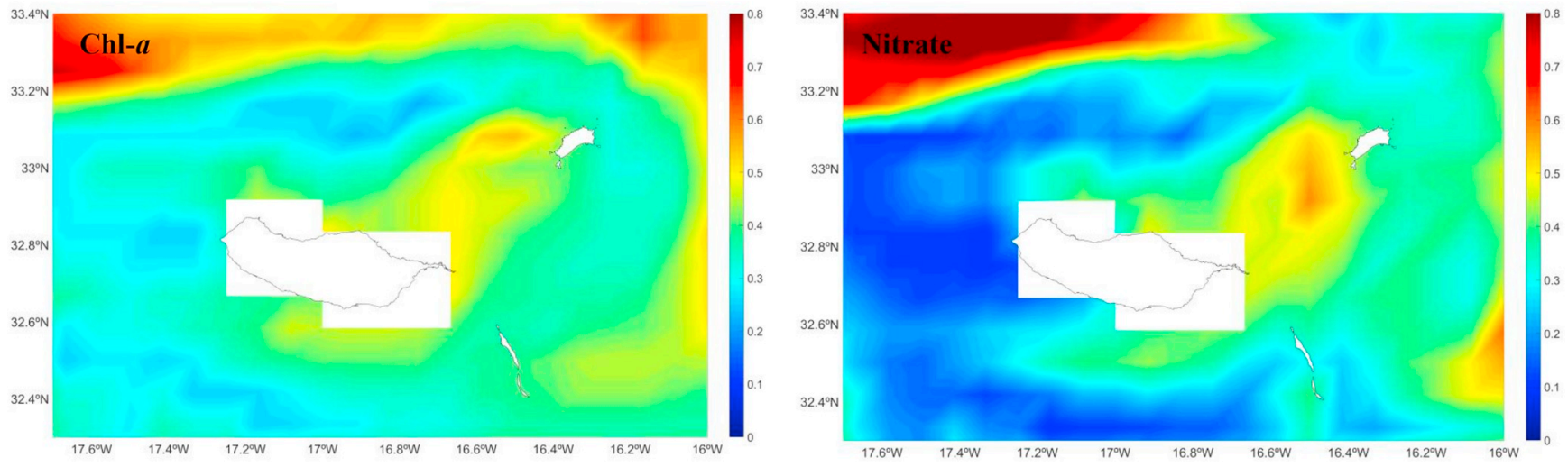

Fig. 8. Model data maps of Chl- $a$ and nitrate based on data obtained from IBI-Bio for the sampling period. 


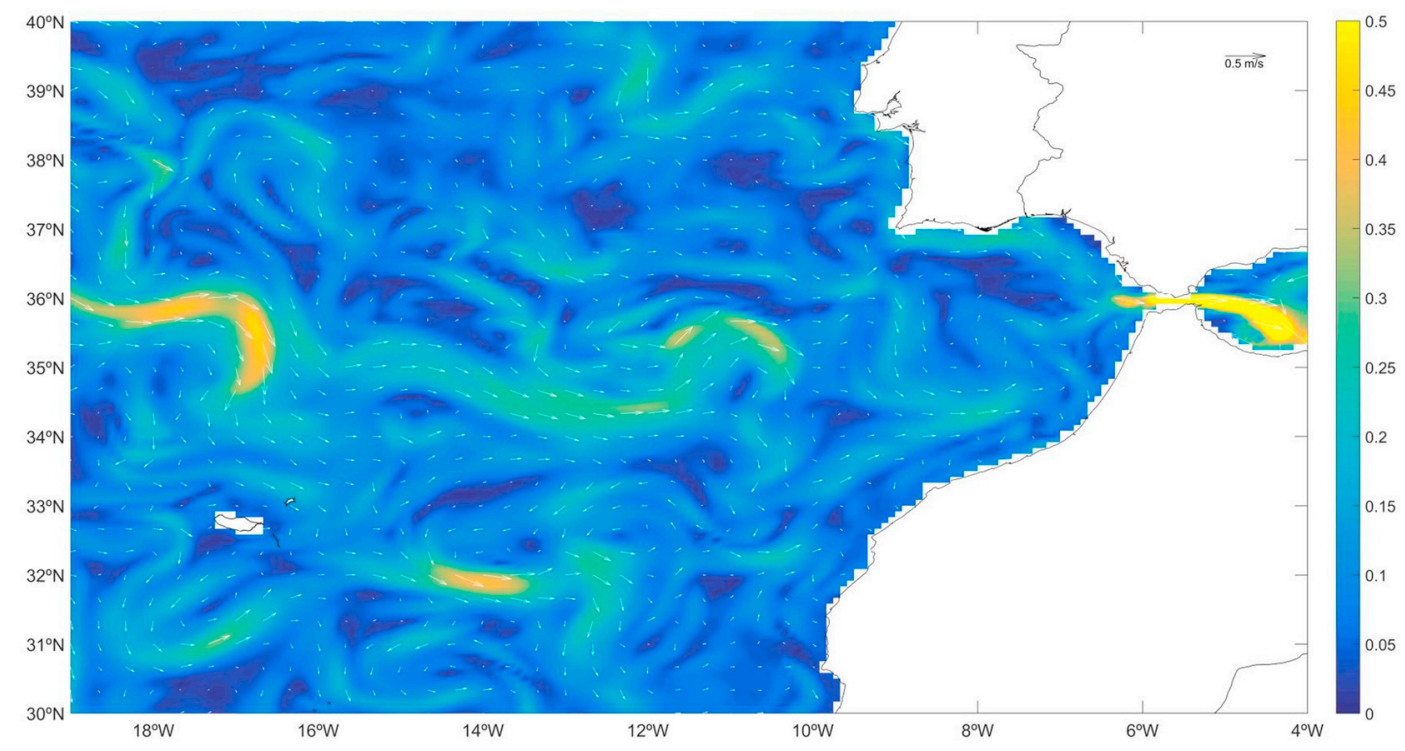

Fig. 9. Model data map of surface currents based on data obtained from IBI-Phys for the sampling period.
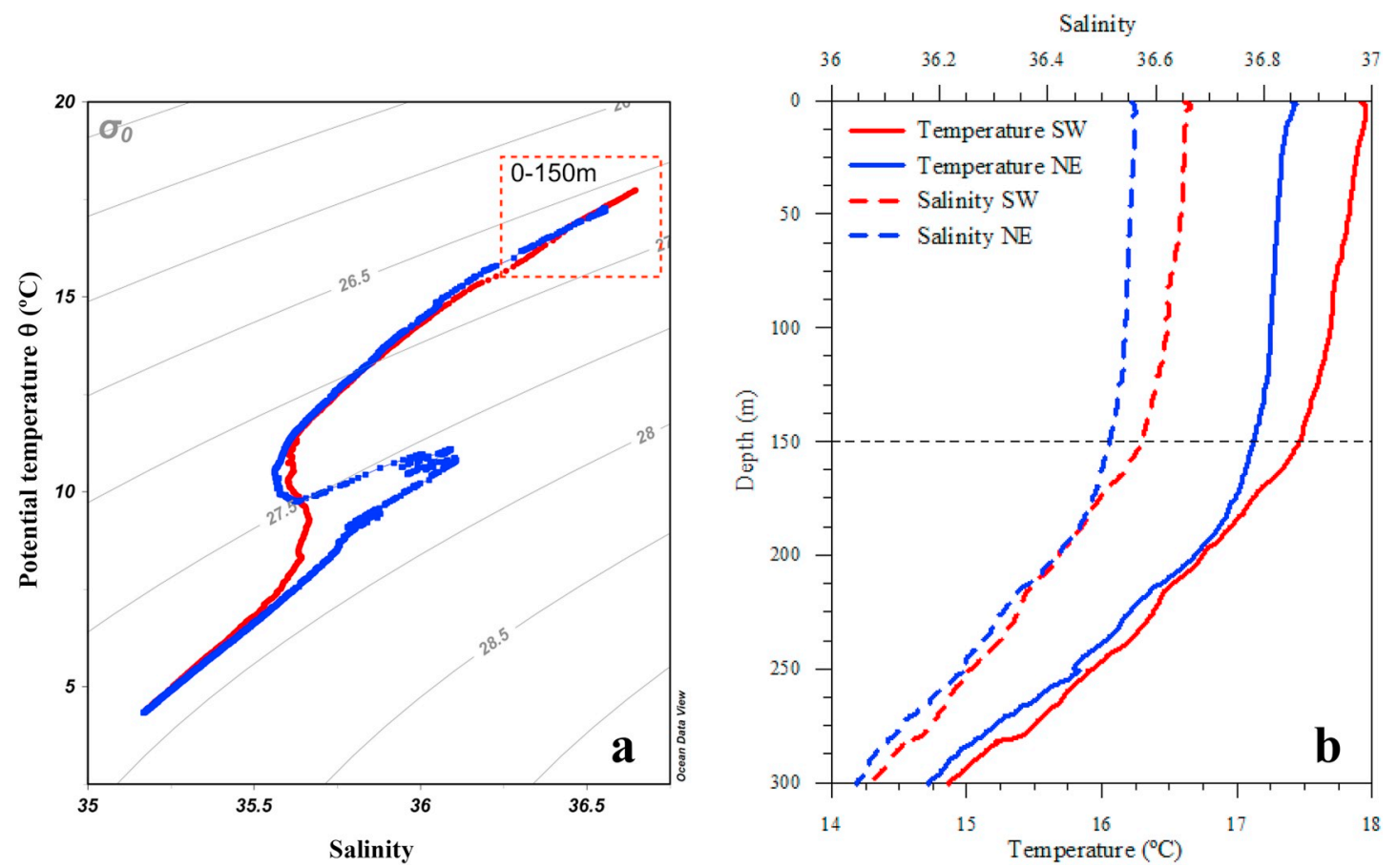

Fig. 10. T-S diagram showing the differences between the NE (blue) and SW (red) water masses. Contour lines of sigma-t, i.e. lines of equal density, are also plotted. The first $150 \mathrm{~m}$ of the water column are indicated (a). Mean temperature and salinity along the uppermost $300 \mathrm{~m}$ water depth, for the two sampling domains, NE and SW (b). (For interpretation of the references to color in this figure legend, the reader is referred to the Web version of this article.)

higher productivity spots but also throughout the Madeira archipelago during the sampling period (Table 2). According to Schiebel et al. (2011), $F$. profunda is absent from the northernmost stations $\left(45^{\circ} \mathrm{N}-47^{\circ} \mathrm{N}\right)$ and present in the southernmost ones $\left(33^{\circ} \mathrm{N}-35^{\circ} \mathrm{N}\right)$. The relative proximity of the southernmost samples to the archipelago of Madeira, and since this oceanographic survey was also carried out at March, we would expect more favorable conditions for the development of the LPZ taxa in the western and southern stations, further away from the frontal zone. However, and as discussed above, the absence of stratification of the water column down to $150 \mathrm{~m}$, during the sampling period, may explain the lack of $F$. profunda, as well as the lack of the coccolithophore vertical succession. In the context of marginal regions, particularly in the NW Iberian coastal upwelling system, a marked seasonal change in the coccolithophore assemblage was noticed
(Ausín et al., 2018). Again, E. huxleyi was the dominant species with cell densities reaching maximum values in March, coincident with the upwelling regime. The coccosphere absolute abundances (outer-shelf station) are in the same order of magnitude of those observed in the most productive areas of the current work. F. profunda was recorded only during winter, related to the downwelling regime and deeper waters. At a sediment trap subtropical station, NW of the Madeira archipelago and also under the influence of the Azores front, E. huxleyi dominated during spring while $F$. profunda and others LPZ species proliferated in the autumn (Broerse et al., 2000). All these observations lead us to infer that coccolithophore abundances off Madeira archipelago are seasonally modulated, due to the seasonal pattern of the oceanographic processes, which are mostly determined by the regional atmospheric circulation. 
Table 8

Variation of temperature, salinity and density, in the first $150 \mathrm{~m}$ depth, for two strategic sites.

\begin{tabular}{lll}
\hline $0-150 \mathrm{~m}$ & North of Porto Santo & South of Madeira \\
\hline$|\Delta \mathrm{T}|$ & 0.23 & 1.09 \\
$|\Delta \mathrm{S}|$ & 0.045 & 0.137 \\
$|\Delta \sigma|$ & 0.028 & 0.171 \\
\hline
\end{tabular}

Gephyrocapsa oceanica, the third most abundant species, showed the highest cell densities closer to the south coast of Madeira, further south and at NW of this island (Fig. 5). The opposition to maximum fluorescence, the proxy for phytoplankton biomass, is also assumed (Fig. 7). These observations suggest $G$. oceanica's preferences for coastal waters, warmer and more saline when compared with E. huxleyi and small Gephyrocapsa. The connection of this species to relatively nutrient-rich coastal waters was also defended by Silva et al. (2008), Guerreiro et al. (2014) and Narciso et al. (2016), although other authors assumed G. oceanica as a maximum upwelling proxy (e.g. Sprengel et al., 2002; Andruleit et al., 2003; Guerreiro et al., 2013; Ausín et al., 2018). In our data the broad depth range of $G$. oceanica was also recognized (Fig. 6), supporting the observations of Houghton and Guptha (1991), Andruleit (2007) and Guerreiro et al. (2014).

Michaelsarsia spp. and Algirosphaera robusta seemed to prefer the NW coast of Madeira island (Fig. 5), where a moderate productive zone can be inferred (Figs. 2, 4 and 8). A. robusta has been considered as belonging to the lower or middle photic zone communities (Winter and Siesser, 1994; Takahashi and Okada, 2000). Similarly, Andruleit (2007) referred A. robusta as part of the deep-photic community, together with F. profunda. On the contrary, in the current research $A$. robusta was relatively well represented at shallower depths (the same in: Jordan and Winter 2000; Malinverno et al., 2003), although the highest densities were observed at $50 \mathrm{~m}$ and $75 \mathrm{~m}$. This, in turn may indicate a deepening of the surface mixed layer, also suggested by Malinverno et al. (2009), and subsequent mesotrophic conditions of this coastal influenced setting, during this time of the year. The highest abundances of Syracosphera spp. were well distributed throughout the archipelago and at depth, possibly due to the great intra genus variability within this group, showing peaks either in more or less productive zones, as well as close to the coast (Silva et al., 2008) or in open ocean conditions (Guerreiro et al., 2014). The highest cell densities of Umbilicosphaera spp. presented a scattered pattern but not coincident with the maximum productivity spots. Although these taxa are also known for its preference for warm and oligotrophic habitats (Winter and Siesser, 1994; Baumann et al., 2016), in the current work display some affinity for mesotrophic conditions, supporting the findings of Hagino and Okada (2006) and Narciso et al. (2016). Although D. tubifera was an uncommon species in the current study, it presented an interesting vertical distribution pattern (Fig. 7). D. tubifera was firstly described as a warm-water species of the upper water layers (Okada and McIntyre, 1979), being observed in the water column down to $50 \mathrm{~m}$ (Haidar and Thierstein, 2001; Malinverno et al., 2003; Oviedo et al., 2015). The presence of this species, in our samples, down to $125 \mathrm{~m}$ may reflect the high degree of mixing of the water column.

The nonexistence of the coccolithophore vertical succession and the permanent presence of several taxa throughout all sampling depths may indicate remote enrichments on cells and nutrients from nearby higher productive areas, e.g. mesoscale eddies of the Azores front branches.

\section{Conclusions}

The present study on the biodiversity and the spatial and vertical distributions of coccolithophores at the Madeira archipelago led to the following main conclusions:

1. Separated by a thermohaline front, with origin in a branch from the Azores current, two biogeographic domains could be distinguished inside the Madeira archipelago during late winter: NE and SW, with 
distinct physical-chemical and calcareous nannoplankton characteristics;

2. In the NE sector, higher coccolithophore cell densities were associated with colder, less saline and assumed higher nutrient content water masses. Opposite characteristics described the SW sector;

3. Due to the occurrence of a homogeneous and well-mixed surface layer down to $150 \mathrm{~m}$ water depth, no vertical succession of coccolithophore species was found;

4. Emiliania huxleyi and small Gephyrocapsa were the dominant taxa, which is compatible with the water column mixing and the subsequent nutrient enrichment;

5. Gephyrocapsa oceanica showed the highest cell densities distributed closer to the south coast of Madeira, further south and at NW of this island, suggesting its preference for coastal waters, warmer and less

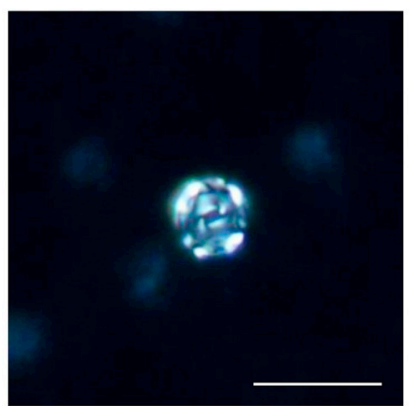

Emiliania huxleyi

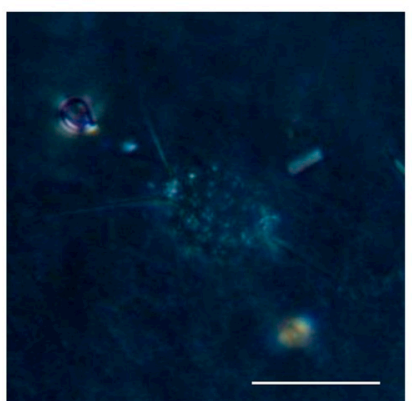

Acanthoica quattrospina

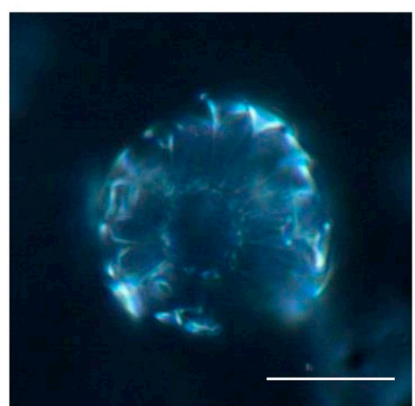

Discosphaera tubifera

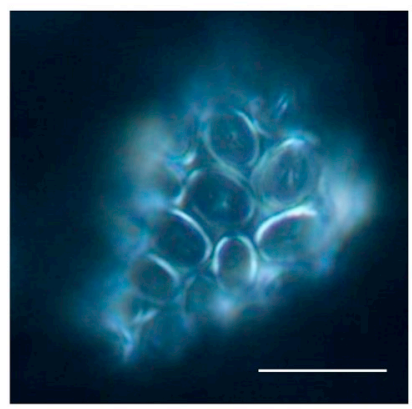

Syracosphaera pulchra

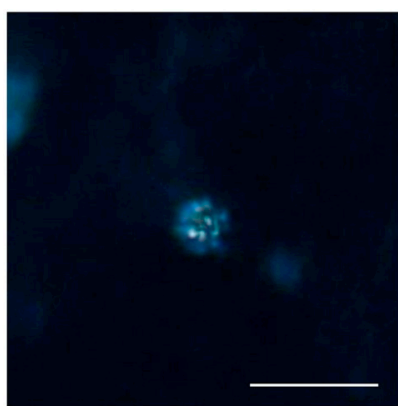

Gephyrocapsa ericsonii

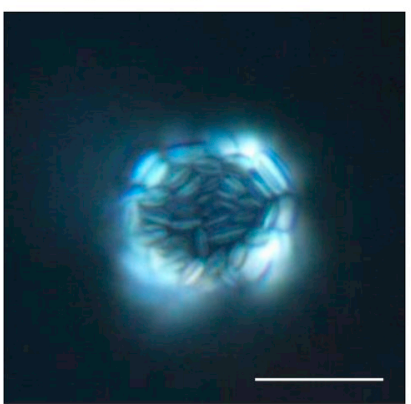

Algirosphaera robusta

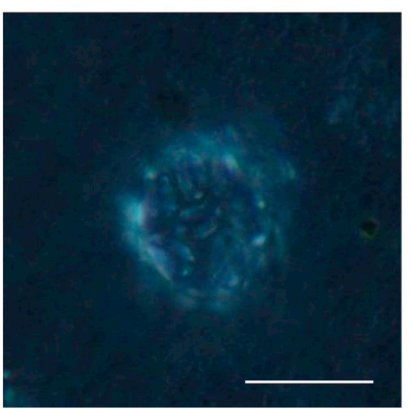

Helicosphaera pavimentum

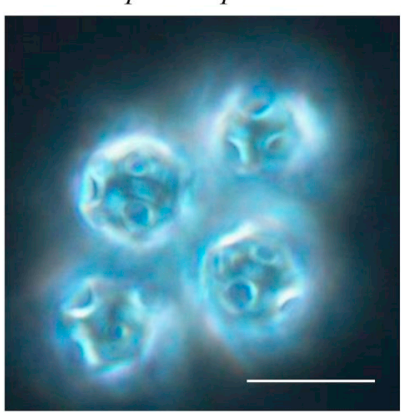

Umbilicosphaera foliosa

turbulent as compared to E. huxleyi and small Gephyrocapsa;

6. Michaelsarsia spp. and Algirosphaera robusta preferred the NW coast of Madeira island, where mesotrophic conditions of the water column seemed to be present during the oceanographic survey;

7. Due to a high biodiversity within Syracosphaera genus, its highest cell densities were observed spread from near coast to open ocean conditions, as well as from lower to higher productive zones;

8. The highest abundances of Umbilicosphaera spp. appeared also dispersed, but not coincident with the maximum productivity sites, displaying some affinity of these taxa for meso to oligotrophic conditions;

9. Local coccolithophore hotspots may be due to remote enrichment by oceanographic features with origin in the Azores frontal system.

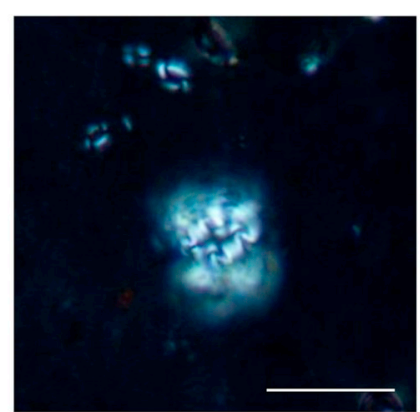

Gephyrocapsa muellerae

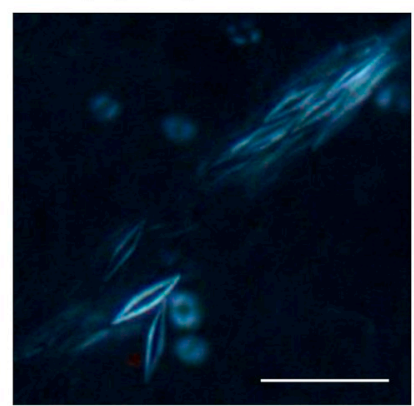

Calciosolenia sp.

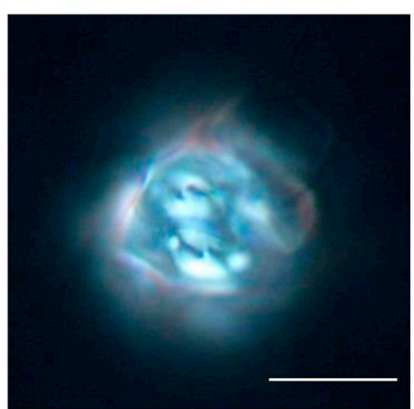

Helicosphaera wallichii

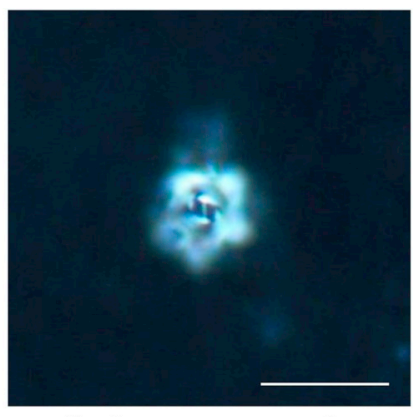

Gephyrocapsa oceanica

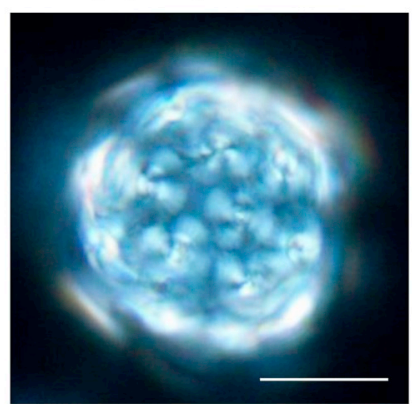

Calcidiscus leptoporus

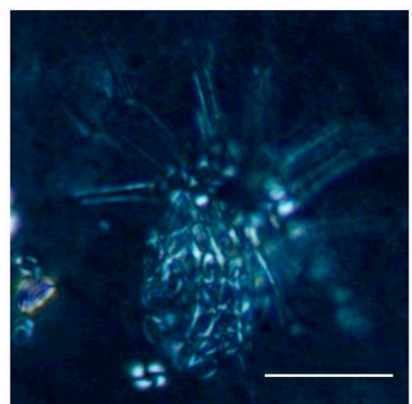

Michaelsarsia sp.

Plate 1. Cross-polarized light microscopy images. All scale-bars are $10 \mu \mathrm{m}$. 


\section{Acknowledgements}

This research was supported by the Madeira's Regional Agency for the Development of Research Technology and Innovation (ARDITI Agência Regional para o Desenvolvimento da Investigação Tecnologia e Inovação) through a post-doc fellowship to AN funded in the scope of the project M1420-09-5369-FSE-000001. This study was also supported by the Oceanic Observatory of Madeira (M1420-01-0145-FEDER000001-Observatório Oceânico da Madeira-OOM). MK was partially supported by the European Regional Development Fund (ERDF) through the COMPETE - Operational Competitiveness Programme and national funds through FCT - Foundation for Science and Technology (Portugal), under the project UID/Multi/04423/2013. The authors are deeply grateful to the captain and crew of the RV Poseidon, cruise POS466, as well as to our colleagues on board for their skillful help and assistance in the sampling operations and for making the cruise successful. Shiptime was provided by the Control Group for the MediumSized Research Vessels to Dr. Kai Horst George, Senckenberg am Meer (Wilhelmshaven, Germany), who kindly made a place available for sampling during the cruise and for providing financial support. Constructive criticism and helpful suggestions from the two anonymous reviewers are gratefully acknowledged by the authors. This is contribution number 46 of the Funchal Marine Biology Station.

\section{Appendix A. Supplementary data}

Supplementary data to this article can be found online at https:// doi.org/10.1016/j.ecss.2019.04.014.

\section{References}

Anderson, R.A., 2005. Algal Culturing Techniques, Algal Culturing Techniques. Elsevier Academic Presshttps://doi.org/10.1017/CBO9781107415324.004.

Andruleit, H., 2007. Status of the Java upwelling area (Indian Ocean) during the oligo trophic northern hemisphere winter monsoon season as revealed by coccolithophores. Mar. Micropaleontol. 64, 36-51. https://doi.org/10.1016/j.marmicro.2007. 02.001 .

Andruleit, H., Stäger, S., Rogalla, U., Čepek, P., 2003. Living coccolithophores in the northern Arabian Sea: ecological tolerances and environmental control. Mar. Micropaleontol. 49, 157-181. https://doi.org/10.1016/S0377-8398(03)00049-5.

Ausín, B., Zúñiga, D., Flores, J.A., Cavaleiro, C., Froján, M., Villacieros-Robineau, N., Alonso-Pérez, F., Arbones, B., Santos, C., de la Granda, F., Castro, C.G., Abrantes, F., Eglinton, T.I., Salgueiro, E., 2018. Spatial and temporal variability in coccolithophore abundance and distribution in the NW Iberian coastal upwelling system. Biogeosciences 15, 245-262. https://doi.org/10.5194/bg-15-245-2018.

Barcelos e Ramos, J., Schulz, K.G., Voss, M., Narciso, A., Müller, M.N., Reis, F.V., Cachão, M., Azevedo, E.B., 2017. Nutrient-specific responses of a phytoplankton community: a case study of the North Atlantic Gyre, Azores. J. Plankton Res. 1-18. https://doi. org/10.1093/plankt/fbx025.

Baumann, K., Boeckel, B., Čepek, M., 2008. Spatial distribution of living coccolithophores along an east- west transect in the subtropical South Atlantic. J. Nannoplankt. Res. 30, 9-21.

Baumann, K.H., Saavedra-Pellitero, M., Böckel, B., Ott, C., 2016. Morphométrie, biogéographie et écologie des genres Calcidiscus et Umbilicosphaera dans l'Atlantique Sud. Rev. Micropaleontol. 59, 239-251. https://doi.org/10.1016/j. revmic.2016.03.001.

Beare, D., McQuatters-Gollop, A., van der Hammen, T., Machiels, M., Teoh, S.J., HallSpencer, J.M., 2013. Long-term trends in calcifying plankton and $\mathrm{pH}$ in the north sea. PLoS One 8. https://doi.org/10.1371/journal.pone.0061175.

Broerse, A.T., Ziveri, P., van Hinte, J.E., Honjo, S., 2000. Coccolithophore export production, species composition, and coccolith-CaCO3 fluxes in the NE Atlantic $\left(34^{\circ} \mathrm{N} 21^{\circ} \mathrm{W}\right.$ and $\left.48^{\circ} \mathrm{N} 21^{\circ} \mathrm{W}\right)$. Deep Sea Res. Part II Top. Stud. Oceanogr. 47, 1877-1905. https://doi.org/10.1016/S0967-0645(00)00010-2.

Buongiorno Nardelli, B., Tronconi, C., Pisano, A., Santoleri, R., 2013. High and ultra-high resolution processing of satellite sea surface temperature data over southern European Seas in the framework of MyOcean project. Remote Sens. Environ. 129, 1-16. https://doi.org/10.1016/J.RSE.2012.10.012.

Caldeira, R.M.A., 2018. Island wakes. In: Encyclopedia of Ocean Sciences, https://doi. org/10.1016/B978-0-12-409548-9.11614-8.

Caldeira, R.M.A., Groom, S., Miller, P., Pilgrim, D., Nezlin, N.P., 2002. Sea-surface signatures of the island mass effect phenomena around Madeira Island, Northeast Atlantic. Remote Sens. Environ. 80, 336-360. https://doi.org/10.1016/S00344257(01)00316-9.

Caldeira, R.M.A., Sangrà, P., 2012. Complex geophysical wake flows Madeira Archipelago case study. Ocean Dynam. 62, 683-700. https://doi.org/10.1007/s10236-0120528-6.
Cromwell, D., Challengor, P.G., 1996. New, persistent westward flow in the Azores current as seen from altimetry and hydrography. J. Geophys. Res. 101 (C5), 11923-11933.

Cros, L., Fortuño, J.-M., 2002. Atlas of Northwestern Mediterranean coccolithophores. Scientia Marina 66 (1), 1-186.

Falkowski, P.G., 1994. The role of phytoplankton photosynthesis in global biogeochemical cycles. Photosynth. Res. 39, 235-258. https://doi.org/10.1007/BF00014586.

Falkowski, P.G., Barber, R.T., Smetacek, V., 1998. Biogeochemical controls and feedbacks on ocean primary production. Science 84 281, 200-206. https://doi.org/10.1126/ science.281.5374.200.

Field, C.B., Behrenfeld, M.J., Randerson, J.T., Falkowsky, P., 1998. Prymary production of the biosphere: integrating terrestrial and oceanic cmponents. Science 281 (5374), 237-240. https://doi.org/10.1016/j.cognition.2008.05.007.

Flores, J.A., Gersonde, R., Sierro, F.J., 1999. Pleistocene fluctuations in the Agulhas Current Retroflection based on the calcareous plankton record. Mar. Micropaleontol. $37,1-22$.

Frada, M., Young, J., Cachão, M., Lino, S., 2010. A guide to extant coccolithophores (Calcihaptophycidae, Haptophyta) using light microscopy. J. Nannoplankt. Res. 31, 58-112.

Geldmacher, J., Hoernle, K., Klügel, A., van den Bogaard, P., Duggen, S., 2006. A geochemical transect across a heterogeneous mantle upwelling: implications for the evolution of the Madeira hotspot in space and time. Lithos 90, 131-144. https://doi. $\operatorname{org} / 10.1016 /$ j.lithos.2006.02.004.

Guerreiro, C., Oliveira, A., de Stigter, H., Cachão, M., Sá, C., Borges, C., Cros, L., Santos, A., Fortuño, J.-M., Rodrigues, A., 2013. Late winter coccolithophore bloom off central Portugal in response to river discharge and upwelling. Cont. Shelf Res. 59, 65-83. https://doi.org/10.1016/j.csr.2013.04.016.

Guerreiro, C., Sá, C., de Stigter, H., Oliveira, A., Cachão, M., Cros, L., Borges, C., Quaresma, L., Santos, A.I., Fortuño, J.-M., Rodrigues, A., 2014. Influence of the Nazaré Canyon, central Portuguese margin, on late winter coccolithophore assemblages. Deep Sea Res. Part II Top. Stud. Oceanogr. 104, 335-358. https://doi.org/10. 1016/j.dsr2.2013.09.011.

Hagino, K., Okada, H., 2006. Intra- and infra-specific morphological variation in selected coccolithophore species in the equatorial and subequatorial Pacific Ocean. Mar. Micropaleontol. 58, 184-206. https://doi.org/10.1016/J.MARMICRO.2005.11.001.

Haidar, A.T., Thierstein, H.R., 2001. Coccolithophore dynamics off Bermuda (N. Atlantic). Deep Sea Res. Part II Top. Stud. Oceanogr. 48, 1925-1956. https://doi.org/ 10.1016/S0967-0645(00)00169-7.

Hammer, Ø., Harper, D.A.T. a. T., Ryan, P.D., 2001. PAST: paleontological statistics software package for education and data analysis. Palaeontol. Electron. 4 (1), 1-9. https://doi.org/10.1016/j.bcp.2008.05.025.

Hay, W.W., 2004. Carbonate fluxes and calcareous nannoplankton. In: Thierstein, H., Young, J. (Eds.), Coccolithophores: From Molecular Process to Global Impact. Springer Verlag., pp. 509-528.

Honjo, S., 1996. Fluxes of particles to the interior of the open oceans. In: Ittekkot, V. (Ed.), Particle Flux in the Ocean, Scope 57. Wiley \& Sons, Chichester, pp. 91-154.

Houghton, S.D., Guptha, M.V.S., 1991. Monsoonal and fertility controls on Recent marginal sea and continental shelf coccolith assemblages from the western Pacific and northern Indian oceans. Mar. Geol. 97, 251-259. https://doi.org/10.1016/00253227(91)90119-O.

Jordan, R.W., Winter, A., 2000. Assemblages of coccolithophorids and other living microplankton off the coast of Puerto Rico during January-May 1995. Mar. Micropaleontol. 39, 113-130. https://doi.org/10.1016/S0377-8398(00)00017-7.

Jordan, R.W., Cros, L., Young, J.R., 2004. A revised classification scheme for living haptophytes. Micropaleontology 50 (supplement 1), 55-79 appendices 1-4.

Juliano, M.F., Alves, M.L.G.R., 2007. The atlantic subtropical front/current systems of Azores and st. Helena. J. Phys. Oceanogr. 37, 2573-2598. https://doi.org/10.1175/ 2007JPO3150.1.

Käse, R.H., Siedler, G., 1982. Meadering of the sub-tropical front southeast of the Azores. Nature 300, 245-246.

Kaufmann, M., 2004. The nannoplankton diversity around Madeira . A first contribution. J. Nannoplankt. Res. 64.

Kaufmann, M.J., Santos, F., Maranhão, M., 2015. Checklist of nanno- and microphytoplankton off Madeira Island (Northeast Atlantic) with some historical notes. Nova Hedwigia 101, 205-232. https://doi.org/10.1127/nova.

Longhurst, A., 1995. Seasonal cycles of pelagic production and consumption. Prog. Oceanogr. 36, 77-167. https://doi.org/10.1016/0079-6611(95)00015-1.

Malinverno, E., Triantaphyllou, M.V., Stavrakakis, S., Ziveri, P., Lykousis, V., 2009. Seasonal and spatial variability of coccolithophore export production at the SouthWestern margin of Crete (Eastern Mediterranean). Mar. Micropaleontol. 71, 131-147. https://doi.org/10.1016/j.marmicro.2009.02.002.

Malinverno, E., Ziveri, P., Corselli, C., 2003. Coccolithophorid distribution in the Ionian Sea and its relationship to eastern Mediterranean circulation during late fall to early winter 1997. J. Geophys. Res. 108, 8115. https://doi.org/10.1029/2002JC001346.

Margalef, R., 1968. Perspectives in Ecological Theory. University of Chicago Presshttps:// doi.org/10.1515/9781400860180.

McClain, C.R., Arrigo, K.R., Esaias, W., Darzi, M., Patt, F.S., Evans, R.H., et al., 1995. In: SeaWiFS Algorithms, Part 1. NASA Tech. Memo. 104566 Vol. 28 NASA Goddard Space Flight Center, Greenbelt, Maryland.

McTaggart, K.E., Johnson, G.C., Delahoyde, M.C.F.H., Swift, J.H., 2010. Notes on CTC/O2 Data Acquisition and Processing Using Sea-Bird Hardware and Software (As Available). In: Hood, E.M., Sabine, C.L., Sloyan, B.M. (Eds.), The GO-SHIP Repeat Hydrography Manual: A Collection of Expert Reports and Guidelines. Version 1, pp. 10. (IOCCP Report Number 14; ICPO Publication Series Number 134). Available online at: http://www.go-ship.org/HydroMan.html.

Narciso, A., Gallo, F., Valente, A., Cachão, M., Cros, L., Azevedo, E.B., e Ramos, J.B., 
2016. Seasonal and interannual variations in coccolithophore abundance off Terceira island, Azores (central north atlantic). Cont. Shelf Res. 117, 43-56. https://doi.org/ 10.1016/j.csr.2016.01.019.

O'Brien, C.J., Peloquin, J. a., Vogt, M., Heinle, M., Gruber, N., Ajani, P., Andruleit, H., Arístegui, J., Beaufort, L., Estrada, M., Karentz, D., Kopczyńska, E., Lee, R., Poulton, a. J., Pritchard, T., Widdicombe, C., 2013. Global marine plankton functional type biomass distributions: coccolithophores. Earth Syst. Sci. Data 5, 259-276. https:// doi.org/10.5194/essd-5-259-2013.

Okada, H., Honjo, S., 1973. The distribution of oceanic coccolithophorids in the Pacific. Deep Sea Res. Oceanogr. Abstr. 20, 355-374. https://doi.org/10.1016/00117471(73)90059-4.

Okada, H., McIntyre, A., 1977. Modern coccolithophores of the Pacific and North Atlantic oceans. Micropaleontology 23 (1), 1-54.

Okada, H., McIntyre, A., 1979. Seasonal distribution of modern coccolithophores in the western North Atlantic Ocean. Mar. Biol. 54, 319-328.

Oviedo, A., Ziveri, P., Álvarez, M., Tanhua, T., 2015. Is coccolithophore distribution in the Mediterranean Sea related to seawater carbonate chemistry? Ocean Sci. 11, 13-32. https://doi.org/10.5194/os-11-13-2015.

Pingree, R.D., Garcia-Soto, C., Sinha, B., 1999. Position and structure of the subtropical/ Azores Front region from combined Langrarian and remote sensing (IR/altimeter/ SeaWiFS) measurements. Journal of the Marine Biological Association ofthe United Kingdom 770-791.

Schiebel, R., 2002. Planktic foraminiferal sedimentation and the marine calcite budget Glob. Biogeochem. Cycles 16https://doi.org/10.1029/2001GB001459. 3-1-3-21.

Schiebel, R., Brupbacher, U., Schmidtko, S., Nausch, G., Waniek, J.J., Thierstein, H.-R., 2011. Spring coccolithophore production and dispersion in the temperate eastern North Atlantic Ocean. J. Geophys. Res. 116, C08030. https://doi.org/10.1029/ 2010JC006841.

Schlitzer, R., 2018. Ocean Data View. https://odv.awi.de/.

Siedler, G., Zenk, W., Emery, W.J., 1985. Strong current events related to a subtropical front in the northeast atlantic. J. Phys. Oceanogr. 15, 885-897.

Silva, A., Palma, S., Moita, M.T., 2008. Coccolithophores in the upwelling waters of Portugal: four years of weekly distribution in Lisbon bay. Cont. Shelf Res. 28, 2601-2613. https://doi.org/10.1016/j.csr.2008.07.009.

Silva, A., Palma, S., Oliveira, P.B., Moita, M.T., 2009. Composition and interannual variability of phytoplankton in a coastal upwelling region (Lisbon Bay, Portugal). J.
Sea Res. 62, 238-249. https://doi.org/10.1016/j.seares.2009.05.001.

Smyth, T.J., Moore, G.F., Hirata, T., Aiken, J., 2006. PML Inherent Optical Property model. Semianalytical model for the derivation of ocean color inherent optical properties: description, implementation, and performance assessment. Applied Optics 45 (31), 8116-8131.

Sotillo, M.G., Cailleau, S., Lorente, P., Levier, B., Aznar, R., Reffray, G., Amo-Baladrón, A., Chanut, J., Benkiran, M., Alvarez-Fanjul, E., 2015. The myocean IBI ocean forecast and reanalysis systems: Operational products and roadmap to the future copernicus service. J. Oper. Oceanogr. 8, 63-79. https://doi.org/10.1080/1755876X.2015. 1014663.

Sprengel, C., Baumann, K.-H., Henderiks, J., Henrich, R., Neuer, S., 2002. Modern coccolithophore and carbonate sedimentation along a productivity gradient in the Canary Islands region: seasonal export production and surface accumulation rates. Deep Sea Res. Part II Top. Stud. Oceanogr. 49, 3577-3598. https://doi.org/10.1016/ S0967-0645(02)00099-1.

Takahashi, K., Okada, H., 2000. Environmental control on the biogeography of modern coccolithophores in the southeastern Indian Ocean offshore of Western Australia. Mar. Micropaleontol. 39, 73-86. https://doi.org/10.1016/S0377-8398(00)00015-3.

Tyrrell, T., Young, J.R., 2009. Coccolithophores. In: Encyclopedia of Ocean Sciences. Elsevier, pp. 606-614. https://doi.org/10.1016/B978-012374473-9.00662-7.

Vilas, J.C., Arístegui, J., Kiriakoulakis, K., Wolff, G.A., Espino, M., Polo, I., Montero, M.F., Mendonça, A., 2009. Seamounts and organic matter - Is there an effect? The case of Sedlo and Seine Seamounts: Part 1. Distributions of dissolved and particulate organic matter. Deep Sea Res. II 56, 2618-2630.

Waniek, J.J., 2003. The role of physical forcing in initiation of spring blooms in the Northeast Atlantic. Journal of Marine Systems 39 (1-2), 57-82.

Winter, A., Jordan, R., Roth, P., 1994. Biogeography of living coccolithophores in ocean waters. In: Winter, A., Siesser, W. (Eds.), Coccolithophores. Cambridge University Press, Cambridge, pp. 161-177.

Winter, A., Siesser, W.G., 1994. Atlas of Living Coccolithophores, Coccolithophores. Cambridge University Presshttps://doi.org/10.1017/S0025315400015496.

Young, J.R., 1994. Functions of Coccoliths. In: Winter, A., Siesser, W.G. (Eds.), Coccolithophores. Cambridge University Press, New York, pp. 13-27.

Young, J., Geisen, M., Cros, L., Kleijne, A., Sprengel, C., Probert, I., Ostergaard, J., 2003. A guide to extant coccolithophore taxonomy. J. Nannoplankt. Res. Spec. Issue 1-121. 